\title{
Posttranslational Modifications and Receptor-Associated Proteins in AMPA Receptor Trafficking and Synaptic Plasticity
}

\author{
Jianxiong Jiang ${ }^{a}$ Vishnu Suppiramaniam ${ }^{b}$ Marie W. Wooten ${ }^{a}$ \\ ${ }^{a}$ Department of Biological Sciences and Program in Cellular and Molecular Biosciences, and \\ ${ }^{b}$ Department of Pharmacal Sciences, Auburn University, Auburn, Ala., USA
}

\section{Key Words}

Long-term potentiation - Memory $\cdot$ Receptor trafficking • Synaptic plasticity $\cdot$ Posttranslational modification $\cdot$ Receptor-associated proteins $\cdot$ PKM $\zeta \cdot P K C \iota / \lambda \cdot p 62$

\begin{abstract}
AMPA-type glutamate receptors (AMPARs) mediate most fast excitatory synaptic transmission in the mammalian brain. It is widely believed that the long-lasting, activity-dependent changes in synaptic strength, including long-term potentiation and long-term depression, could be the molecular and cellular basis of experience-dependent plasticities, such as learning and memory. Those changes of synaptic strength are directly related to AMPAR trafficking to and away from the synapse. There are many forms of synaptic plasticity in the mammalian brain, while the prototypic form, hippocampal CA1 long-term potentiation, has received the most intense investigation. After synthesis, AMPAR subunits undergo posttranslational modifications such as glycosylation, palmitoylation, phosphorylation and potential ubiquitination. In addition, AMPAR subunits spatiotemporally associate with specific neuronal proteins in the cell. Those posttranslational modifications and receptor-associated proteins play critical roles in AMPAR trafficking and regulation of AMPAR-dependent synaptic plasticity. Here, we summarize recent studies on posttranslational modifications and associated proteins of AMPAR subunits, and their roles in receptor trafficking and synaptic plasticity.
\end{abstract}

Copyright $\odot 2007$ S. Karger AG, Basel

\section{KARGER}

Fax +41613061234

E-Mail karger@karger.ch

www.karger.com
(C) 2007 S. Karger AG, Basel

Accessible online at:

www.karger.com/nsg

\section{Introduction}

Glutamate and Receptors

The amino acid glutamate is the primary neurotransmitter in excitatory synapses of the vertebrate central nervous system (CNS) and peripheral nervous system (PNS). After release from the presynaptic nerve terminal, glutamate binds to specific receptors on the postsynaptic membrane to conduct excitatory transmission. There are two main types of glutamate receptors (GluRs): ionotropic glutamate receptors (iGluRs), which are ligandgated ion channels that mediate the fast synaptic transmission, and metabotropic glutamate receptors (mGluRs), which are associated with GTP-binding proteins to exert their physiological effects. Based on their affinity for selective structural analogues of glutamate, iGluRs can be classified into three subtypes: $\alpha$-amino-3-hydroxy-5methyl-4-isoxazolepropionic acid (AMPA)-type receptor (AMPAR), kainate (KA)-type receptor (KAR), and $N$ methyl-D-aspartate (NMDA)-type receptor (NMDAR) (fig. 1A) [1-3].

\section{AMPAR Structure}

AMPARs are heterotetrameric cation channels composed of 4 subunits: GluR1-4 (or GluRA-D), each of which comprises about 900 amino acids with a molecular weight of about $105 \mathrm{kDa}$, and shares $68-74 \%$ amino acid sequence identity. There is also about $70 \%$ sequence homology among genes encoding each subunit (fig. 1A) [4]. AMPARs are highly conserved among mammals. For ex-

Dr. Marie W. Wooten

Department of Biological Sciences, Auburn University

331 Funchess Hall, Auburn, AL 36849 (USA)

Tel. +1 334844 9226, Fax +1 3348449234

E-Mailwootemw@auburn.edu 
Fig. 1. AMPAR structure and posttranscriptional modifications. A Phylogenetic tree of ionotropic glutamate receptor (iGluR) subunits. AMPAR $=\alpha$-Amino-3hydroxy-5-methyl-4-isoxazole-propionic acid receptor; $\mathrm{KAR}=$ kainate receptor; NMDAR $=N$-methyl-D-aspartate receptor; GluR = glutamate receptor subunit; $\mathrm{KA}=\mathrm{KAR}$ subunit; NR = NMDAR subunit. B Schematic of AMPAR subunit at the synaptic membrane. Each subunit consists of an extracellular N-terminus, four hydrophobic regions (TM1-4), two intracellular loops, one extracellular loop and an intracellular C-terminus. TM2 domain is a reentrant transmembrane hairpin structure that forms the cation pore channel. The extreme $\mathrm{N}$-terminus contains an $\mathrm{X}$-domain and its function remains unknown. The ligand-binding core is composed of two ligand-binding domains: S1 and S2. The intracellular C-terminus is the interaction site for several proteins. C Posttranscriptional modifications of AMPAR subunits. All subunits undergo the flip/flop alternative splicing. GluR2 and GluR4 also contain another alternative splicing site in the Cterminus to produce the long and short isoforms, whereas GluR1 only has the long isoform and GluR3 only has the short isoform. In addition, GluR2 contains the Q/R RNAediting site within the TM2 domain, and GluR2, 3 and 4 have the R/G RNA-editing site right preceding the flip/flop site.

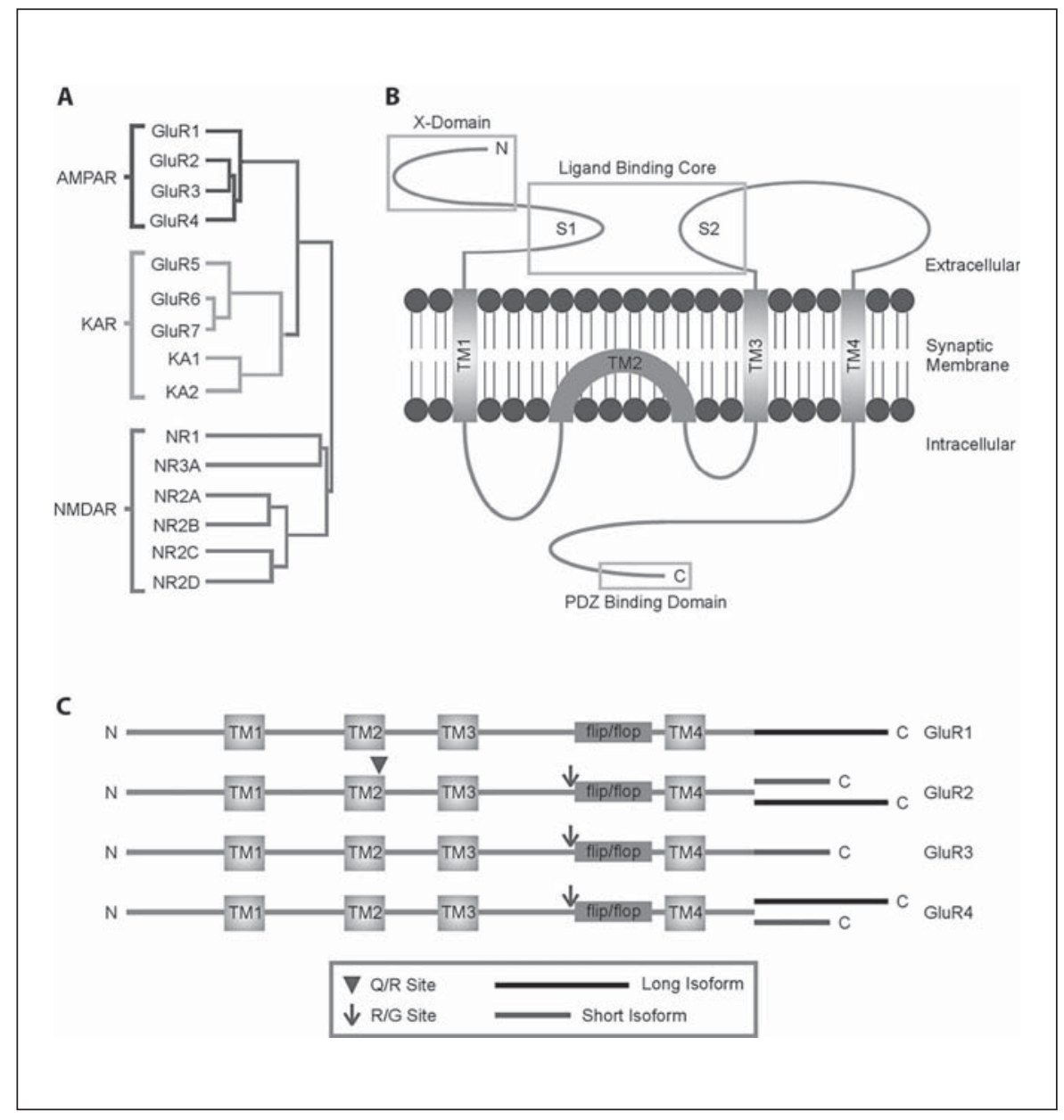

ample, rat, mouse and human GluR1s share 96-97\% identical amino acid sequence. Heteromers of GluR1GluR2 and GluR2-GluR3 predominantly appear in the mature mammalian hippocampus, whereas GluR4-containing forms mainly appear in early postnatal development $[5,6]$. Each AMPAR subunit consists of an extracellular N-terminus, three transmembrane-spanning domains (TM1, TM3 and TM4), one re-entrant transmembrane domain (TM2) and an intracellular C-terminus. Therefore, the transmembrane domains form two intracellular loops (L1-2 and L2-3) and one extracellular loop (L3-4). The extracellular N-terminus has two domains: the $\mathrm{X}$-domain and the $\mathrm{S} 1$ ligand-binding domain. The X-domain comprises about 400 amino acids and its function is unknown. The S1 ligand-binding domain comprises about 100 amino acids. The other extracellular binding domain S2 is in the L3-4 extracellular loop. S1 and S2 domains form the ligand-binding core. The re-entrant TM2 domain contributes to the cation pore chan- nel. The intracellular C-terminus is the interaction site for a variety of proteins, which are related to the receptor modification, trafficking and signaling (fig. 1B) $[2,7]$.

\section{Posttranscriptional Modifications and Receptor Characteristics}

In addition to the variation in combinations of subunits, some posttranscriptional modifications also contribute to AMPAR diversity (fig. 1C). All four AMPAR subunits are subject to alternative splicing that can produce two forms: flip and flop. These are encoded by exons 14 and 15 in GluR2, respectively. The splicing position immediately precedes the TM4 domain [8]. The pharmacological properties of the two spliced forms do not show too much difference, but the flip channels are more efficient because they desensitize at a rate that is four times slower than the flop channels. Expression of the two spliced forms shows different cellular distribution and developmental regulation in the brain. For example, in hippo- 
campus, only flip forms are found in the CA3 pyramidal cells, whereas there are more flop forms than flip forms in dentate gyrus granule cells. Moreover, flip forms predominantly appear before birth. In contrast, the expression level of flop forms continuously increases after birth up to a level similar to that of the flip forms in the adult [1]. In addition, GluR2 and GluR4 also undergo another alternative splicing in the $\mathrm{C}$-terminal tail to produce long isoforms and short isoforms $[9,10]$. Only a small percentage of GluR2 displays a long C-terminus, whereas the long isoform of GluR4 is dominant. The short isoform of GluR4 is mainly found in the cerebellum [9]. GluR1 exists only as the long isoforms and the GluR3 exists only as the short isoforms because of the lack of C-terminal splicing sites.

RNA editing also increases the molecular diversity of AMPAR. In the GluR2, a glutamine codon (CAG) within the TM2 domain is edited to an arginine codon (CIG) (Q/R). Therefore, the GluR2-containing AMPAR, the dominant form in the hippocampus, shows low channel conductance and impermeability to $\mathrm{Ca}^{2+}$, and allows ion influx and efflux, depending on the cell membrane potential. By contrast, the AMPAR lacking GluR2 subunit only allows ion flow into the cell $[11,12]$. In addition, in GluR2, GluR3 and GluR4 mRNA, an arginine codon (AGA) preceding the flip/flop site can be altered to a glycine codon (IGA) $(\mathrm{R} / \mathrm{G})$, which changes the receptor kinetics properties of desensitization and resensitization [13]. The process of RNA editing is fulfilled by RNA-dependent adenosine deaminase 2 (ADAR2) [14-16].

Composition of the subunits, post transcriptional modifications, and especially RNA editing, endow AMPARs with substantial diversity and also determine the ion channel characteristics of the receptor. In response to ligand binding, cations $\mathrm{Na}^{+}$and $\mathrm{Ca}^{2+}$ flow into the cell through AMPARs. Consequently, a fast excitatory postsynaptic response is transmitted. $\mathrm{Ca}^{2+}$ is an important second messenger that activates a variety of protein kinases to initiate a series of signaling pathways, which in turn mediate AMPAR modifications and trafficking to promote and maintain synaptic plasticity $[7,17]$.

\section{AMPAR and Synaptic Plasticity}

In 1973, Bliss and Lømo [18] demonstrated that repetitive activation of excitatory synapses with high-frequency stimulation (HFS) in the hippocampus, a brain area essential for learning and memory, could cause an enhancement in synaptic strength that could last for hours, days, and even weeks. They defined this long-lasting synaptic strength as long-term potentiation (LTP). In the past two decades, it has been widely accepted that this long-lasting, activity-dependent change in synaptic strength could be the molecular and cellular basis of experience-dependent plasticities, including learning and memory [19-23], and even drug addiction $[24,25]$. Since the discovery of hippocampal CA1 LTP, a variety of other forms of synaptic plasticity have been discovered in the CNS including NMDAR-dependent long-term depression (LTD), NMDAR-independent LTP at moss fiber synapses in the hippocampus, mGluR-dependent LTD in the cerebellum, and endocannabinoid-mediated LTD [25]. The prototypic form of plasticity, NMDAR-dependent LTP, generated at excitatory synapses in hippocampal CA1 pyramidal cells, received the widespread attention $[20,26]$.

The process of LTP can be divided into two phases: induction or early LTP (E-LTP), initiating synaptic strength, and maintenance or late LTP (L-LTP), retaining the enhancement of synaptic strength for a long time. Interestingly, there is a parallel between LTP and memory, which also has two components: short-term memory and long-term memory [22]. To induce LTP, glutamate is released from the presynaptic membrane and binds to AMPARs and NMDARs. Release of $\mathrm{Mg}^{2+}$ blockade activates NMDARs to allow $\mathrm{Na}^{+}$and $\mathrm{Ca}^{2+}$ to flow into the dendritic spine through NMDARs. Increasing $\mathrm{Ca}^{2+}$ in the dendritic spine binds to calmodulin (CaM) to activate the CaM kinase II (CaMKII) [26, 27]. Other kinases involved in LTP induction include cAMP-dependent protein kinase (PKA) [28, 29], protein kinase C (PKC) [30-32], extracellular signal-regulated kinase (ERK) in the mitogenactivated protein kinase (MAPK) cascade [33], phosphatidylinositol 3-kinase ( $\mathrm{PI}_{3}$-kinase) $[34,35]$, and tyrosine kinase Src [36]. Some phosphatases are also critical for regulation of LTP [37]. The induction of LTP may be involved in multiple intracellular cascades that are redundant and as yet unidentified $[38,39]$. Maintenance of LTP requires the synthesis of new proteins. These proteins include AMPAR subunits, some transcriptional factors, and structural proteins to enhance existing synapses by enlarging of dendritic spines and forming new connections $[40,41]$.

\section{Subunit Rules in Receptor Trafficking}

The C-terminal cytoplasmic tail of each AMPAR subunit is unique and could be associated with specific regulatory proteins. These proteins impart distinct spatiotemporal patterns of trafficking and localization to each subunit. Combining the subunits to form heterotetramers introduces more complications. Interestingly, in GluR1 knockout mice, the hippocampal CA1 LTP was absent, and a specific spatial working memory was im- 
Fig. 2. AMPAR trafficking from ER to Golgi apparatus and synapse. A After assembly, GluR1-GluR2 heteromers are rapidly transferred from ER to the cis face of Golgi apparatus through interaction between the GluR1 and PDZ protein synapse-associated protein 97 (SAP97), whereas GluR2-GluR3 heteromers exit the ER much more slowly and require interaction between GluR2 C-terminus and protein interacting with $\mathrm{C}$ kinase 1 (PICK1), another PDZ protein. A fraction of GluR2 is retained in the ER with chaperones for an unknown reason. B The interaction between the GluR2 C-terminus and PDZ protein glutamate receptor-interacting protein 1/AMPAR-binding protein (GRIP1/ABP) is necessary for AMPAR trafficking in dendrites along the microtubular cytoskeleton. Liprin- $\alpha$ serves as an adaptor to link GRIP/ABP with KIF1A, a motor protein. Later, AMPARs are targeted to the dendritic spine along actin filaments through the interaction between the C-terminus of GluR1/GluR4 and protein 4.1N. C GluR2-GluR3 receptors continuously and rapidly cycle in and out of synapses to maintain the total number of AMPARs at synapses, whereas GluR1-GluR2 receptors and GluR4-containing receptors are added into synapses via the extrasynaptic surface during expression of LTP. D With induction of LTD, receptors are internalized rapidly.

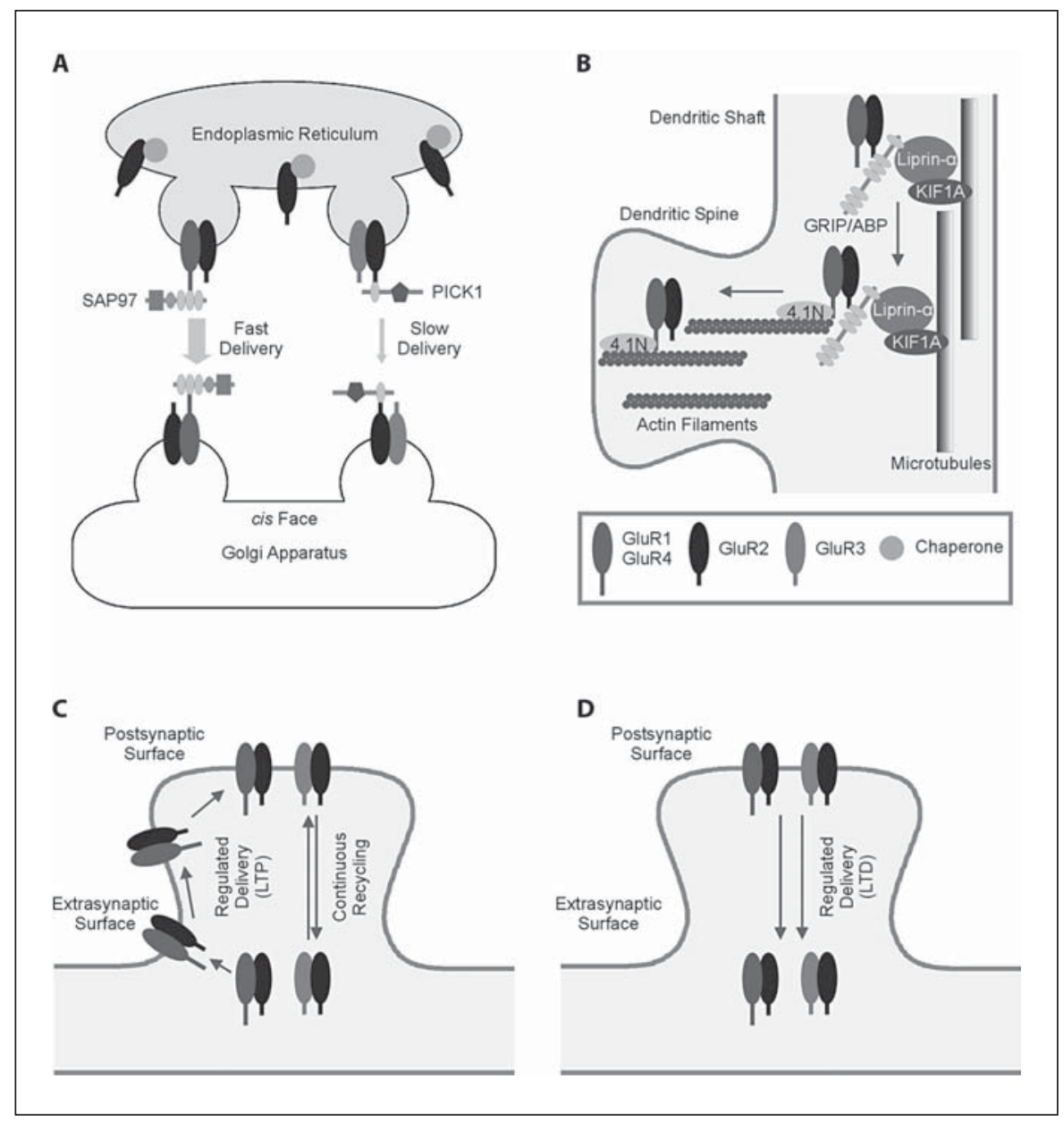

paired [42-44]. No GluR1-containing AMPARs were delivered to the cell membrane, and no LTP was expressed. These results suggest that the AMPAR subunit GluR1 is critical for LTP expression. Consistently, GluR1 exerts dominant effects over GluR2 in the GluR1-GluR2 heteromeric receptors and controls receptor trafficking and distribution [45-47]. Next, we will focus on the roles of posttranslational modifications and AMPAR-associated proteins in receptor trafficking during synaptic plasticity.

\section{AMPAR Trafficking Regulated by Posttranslational Modifications}

Since AMPAR mediates most fast excitatory transmission, its trafficking and cellular distribution must be highly regulated to properly conduct the correct neuronal signals $[29,48]$. After synthesis, AMPAR subunits form heteromers in the endoplasmic reticulum (ER) and the N-terminus of each subunit is critical for the assembly. GluR1-GluR2 heteromers are transferred from the ER to the cis face of Golgi apparatus rapidly through interaction between the GluR1 C-terminus and PDZ protein synapse-associated protein 97 (SAP97) [49]; GluR2GluR3 heteromers exit the ER much more slowly and require interaction between the GluR2 C-terminus and protein interacting with $\mathrm{C}$ kinase 1 (PICK1), another PDZ protein (fig. 2A). A portion of GluR2 is retained in the ER as a complex with some chaperones and the function is unknown [50], but the unique GluR2 Q/R RNA editing may be critical [51]. Most of AMPARs are found in the cell body, so they need to undergo a long journey from the trans face of the Golgi apparatus to the dendritic spine, where the receptors can exert their functions (fig. 2A). The process is microtubule and actin filament-based and requires some AMPAR subunit interaction proteins as adapters, such as PDZ protein glutamate receptor-interacting protein 1/AMPAR bind- 
ing protein (GRIP1/ABP) [52, 53], and protein 4.1N [54]. In the last step, AMPARs reach the synapses through two different pathways (fig. 2B). GluR2-GluR3 receptors continuously and rapidly cycle in and out of synapses to maintain the amount of AMPARs at synapses, whereas GluR1-GluR2 receptors and GluR4-containing receptors are added into synapses during synaptic plasticity $[21,45,46,55]$. In basal conditions, surface insertion of GluR1-GluR2 receptors is slow. While in response to NMDAR activation, receptors are driven into the dendritic spine and redistributed in the dendrites [56]. The delivery routes of the two AMPARs are also different: GluR1-GluR2 receptors are inserted into the extrasynaptic membrane, and later delivered laterally along dendrites to reside stably at the synapse in response to the afferent stimulation, whereas GluR2GluR3 receptors are inserted more directly into the synaptic membrane $[45,46]$. Real-time receptor trafficking also revealed that intracellular AMPARs are delivered into the synaptic membrane via the extrasynaptic and somatic surface, whereas the direct exchange of intracellular receptors with synaptic receptors is slow [57].

It is clear that trafficking of AMPARs to and away from synapses is a mechanism to modulate synaptic strength [21, 24, 27, 29, 58-67]. During LTP expression, more AMPARs are delivered to the postsynaptic membrane (fig. 2C). In contrast, LTD induces receptor internalization (fig. 2D). These findings support the idea that alterations in synaptic strength are directly related to the receptor exocytosis and endocytosis, while AMPAR trafficking is primarily regulated through posttranslational modifications and receptor-associated proteins $[63,68]$.

\section{Glycosylation and Receptor Stability}

Glycosylation can protect proteins from proteolytic degradation. Each AMPAR subunit can be $N$-glycosylated at 4-6 different sites located in the extracellular domains of the protein. Glycosylation increases the receptor subunit molecular weight by about $4 \mathrm{kDa}$. Ligand binding on crystallized unglycosylated GluR2 S1-S2 domains shows that this protein modification is not necessary for ligand recognition [69]. However, the desensitization-inhibiting lectin concanavalin A (ConA) can potentiate AMPAR subunit except GluR2 currents by direct binding to these carbohydrate side chains [70]. Therefore, $N$-glycosylation mainly facilitates the AMPAR maturation, protects the receptor from proteolytic degradation, and may affect receptor current amplitudes as well. However, the lack of $\mathrm{N}$-glycosylation does not significantly affect AMPAR subunit synthesis, assembly, or trafficking $[3,70]$.

\section{Palmitoylation and Receptor Localization}

Palmitoylation of protein is a reversible fatty acylation and regulates protein trafficking and cellular localization. All AMPAR subunits can be palmitoylated at two cysteine sites: one in the transmembrane domain TM2, the other in the intracellular C-terminal region. TM2 palmitoylation results in accumulation of AMPARs in the Golgi apparatus and consequently, a decrease of receptor expression in the cell surface. C-terminal palmitoylation reduces the interaction between receptor and protein $4.1 \mathrm{~N}$ and mediates agonist-induced AMPAR internalization. Therefore, depalmitoylated receptors are stabilized at the cell surface, whereas palmitoylated receptors are more susceptible to internalization triggered by ligand binding. In addition, activation of GluRs by glutamate stimulation decreases receptor palmitoylation and recruits more AMPARs to the cell surface to mediate synaptic plasticity [71].

\section{Phosphorylation and Receptor Activation}

Phosphorylation is the most important molecular mechanism to regulate the ligand-gated ion channels. It can regulate the physiological properties of the channel as well as protein trafficking. With the exception of GluR3, all AMPAR subunits have been reported to be phosphorylated on several amino acid residues by a variety of kinases.

To date, three phosphorylation sites of GluR1 have been reported. All sites are located at the intracellular Cterminus of GluR1. Serine 831 (S831) can be phosphorylated by both PKC [30] and calcium CaMKII [72]; serine 845 (S845) is a protein kinase A (PKA) phosphorylation site [30]. Phosphorylations in S831 and S845 are thought to be important for regulating the GluR1-containing AMPAR trafficking and differentiation of two prototypic synaptic plasticities: hippocampal NMDA-dependent LTP and LTD. According to plasticity history, synapses can be classified into three groups: depressed, naive, and potentiated. LTD induction decreases phosphorylation of S845 in naive synapses and phosphorylation of S831 in potentiated synapses, whereas LTP induction increases phosphorylation of S831 in naive synapses and the phosphorylation of S845 in depressed synapses. In the process, dephosphorylation is introduced by phosphatase PP1/2A [37]. The details that describe how phosphorylation regulates surface expression of AMPAR are not clear, but S845 phosphorylation may facilitate extrasynaptic delivery of GluR1-containing AMPARs and NMDAR activation drives receptors to synapses from extrasynaptic sites by lateral diffusion $[45,73]$. It is important to note 
that both $\mathrm{S} 831$ and S845 are necessary, but not sufficient to deliver AMPARs into synapses. Therefore, other signaling events may be also involved $[74,75]$. In addition, transgenic mice with mutations in S831 and S845 still show reduced LTP, although a lack of LTD [76]. Another PKC phosphorylation site in the C-terminus of GluR1, serine 818 (S818), has been reported recently [32]. Phosphorylation of GluR1 S818 is critical in LTP-driven incorporation of AMPARs into the postsynaptic membrane and is suggested to exert its function by facilitating the interaction between GluR1 and a delivery or tethering protein.

PKC phosphorylates GluR2 at serine 880 (S880) in the C-terminal sequence (IESVKI) for PDZ domain binding to differentially regulate the interaction with $\mathrm{PDZ}$ proteins: GRIP1/ABP and PICK1 [77, 78]. Phosphorylation of GluR2 S880 by PKC activation decreases receptor binding to GRIP1, and recruits PICK1 to synapses and facilitates rapid internalization of surface receptors. This indicates GluR2 phosphorylation of S880 is particularly important in regulating the AMPAR internalization during synaptic plasticity. In fact, GluR2 phosphorylation of S880 is a critical event in the induction of cerebellar LTD, not a NMDAR-dependent, but a metabotropic glutamate receptor mGluR1-dependent form of plasticity [79]. Interestingly, another phosphorylation on tyrosine 876 (Y876) of GluR2 introduced by Src family tyrosine kinases has almost the same effects on GluR2 binding to GRIP1/ABP and PICK1, and in turn facilitates the AMPA- or NMDAinduced receptor internalization [36]. In addition, serine 863 of the GluR2 C-terminus is another potential PKC phosphorylation site and its function remains unknown [80].

Like GluR1, GluR4 is a long isoform of AMPAR subunit. The expression of GluR1 and GluR4 in hippocampus is altered during development. GluR4 is critical for the synaptic plasticity during the early postnatal period when GluR1 expression in the hippocampus is low, whereas in the adult hippocampus GluR4 expression level is low and GluR1 is critical for synaptic function [81]. These two long isoform subunits share the conserved PKA phosphorylation site: S845 of GluR1 and S842 of GluR4. Interestingly, phosphorylation of GluR1 S845 is required, but not sufficient for LTP induction, which also needs S818 and S831 phosphorylations, and the PDZbinding site. In contrast, phosphorylation of GluR4 S842 is both necessary and sufficient to deliver the receptor to the synapse and induce plasticity in early postnatal development [75]. In addition, PKC $\gamma$ is reported to directly interact with the GluR4 and phosphorylate it at serine 482
(S482) in vitro, thereby increasing recombinant GluR4 surface expression to mediate the function of GluR4-containing AMPARs [82]. Threonine 830 (T830) is another potential PKC phosphorylation site of GluR4 and its function remains unknown [83].

\section{PKC Isoforms and AMPA Phosphorylation}

Taken together, receptor phosphorylation by kinases, specifically CaMKII and PKC, play critical roles in AMPAR trafficking and plasticity expression. Notably, several members of the PKC family directly phosphorylate AMPAR subunits to mediate plasticity $[30,32,77,80$, $82,83]$. Recently, a special atypical PKC (aPKC) isoform, $\mathrm{PKM} \zeta$ has received considerable attention and undergoes intense investigation. Vertebrates express 10 PKC isoforms classified into three groups: conventional PKC (cPKC: $\alpha, \beta I, \beta I I$ and $\gamma$ ), novel PKC (nPKC: $\delta, \varepsilon, \eta / L$ and $\theta$ ), and atypical PKC (aPKC: $\zeta$ and $\iota / \lambda$ ) (fig. $3 A$ ). Each isozyme consists of an $\mathrm{N}$-terminal regulatory region and a conserved C-terminal catalytic domain. The regulatory region contains a pseudosubstrate, an autoinhibitory sequence, which automatically interacts with the catalytic domain and blocks the enzymatic activity. Release of the pseudosubstrate by stimulation of second messengers activates the enzyme [84]. PKM $\zeta$ is an isoform of $\mathrm{PKC} \zeta$ without the regulatory region (fig. 3B). This unique characteristic enables the enzyme to be constitutively activated $[85,86]$. PKM $\zeta$ is produced from $\mathrm{PKM} \zeta$ mRNA, transcribed from an internal promoter within the $\mathrm{PKC} \zeta$ gene (fig. 3C) [86]. Interestingly, phosphorylation introduced by $\mathrm{PKM} \zeta$ is necessary and sufficient for LTP maintenance $[87,88]$. In addition, a PKM $\zeta$ inhibitor, myristoylated $\zeta$ pseudosubstrate inhibitory peptide (ZIP), both reverses LTP maintenance in vivo and leads to loss of spatial information. These findings suggest that the LTP maintenance mediated by $\mathrm{PKM} \zeta$ sustains spatial memory [23]. A recent study showed that two sequential steps are involved in LTP maintenance: synthesis and activation of $\mathrm{PKM} \zeta$. $\mathrm{PI}_{3}-$ kinase, CaMKII, MAPK, PKA, mTOR (mammalian target of rapamycin) and preexisting $\mathrm{PKM} \zeta$ regulate de novo synthesis of $\mathrm{PKM} \zeta$ and phosphoinositides-dependent protein kinase-1 (PDK1) activates $\mathrm{PKM} \zeta$ via phosphorylation of its activation loop [89]. Indeed, PKM $\zeta$ causes synaptic potentiation by increasing the number of active AMPARs at the postsynaptic membrane without affecting the unit conductance of receptor channels [90]. This indicates that phosphorylation induced by $\mathrm{PKM} \zeta$ mediates AMPAR trafficking, instead of altering channel properties. 
Fig. 3. The specific structure enables PK$\mathrm{M} \zeta$ to maintain LTP. A PKC family has 10 isoforms classified into three groups: conventional PKC (cPKC: $\alpha, \beta$ I, $\beta$ II and $\gamma$ ), novel PKC (nPKC: $\delta, \varepsilon, \eta / \mathrm{L}$ and $\theta$ ), and atypical PKC (aPKC: $\zeta$ and $\iota / \lambda$ ). Each isozyme consists of an $\mathrm{N}$-terminal regulatory region, which contains cysteine-rich domains (C-1 and C-2) and a pseudosubstrate, and a conserved C-terminal catalytic domain with of serine/threonine kinase activity. B The pseudosubstrate in the regulatory region automatically interacts with the catalytic domain and blocks the activity of the enzyme. Release of the pseudosubstrate by stimulation of the second messengers can activate the enzyme. PKM $\zeta$ is an isoform of $\mathrm{PKC} \zeta$ without the regulatory region, so this enzyme is constitutively activated. C Afferent stimulation activates the NMDARs and causes $\mathrm{Ca}^{2+}$ influx into the dendrite, which in turn activates various $\mathrm{Ca}^{2+}$-dependent kinases to enhance the conductance of receptor channels, to induce LTP expression or early LTP (ELTP). The influx of $\mathrm{Ca}^{2+}$ also triggers an unknown signaling cascade toward the nucleus. As a result, a transcriptional factor binds the internal promoter (P2) of the PK$\mathrm{C} \zeta$ gene to initiate the $\mathrm{PKM} \zeta \mathrm{mRNA}$ transcription. The PKM $\zeta$ mRNA is actively transported to dendrites and produces PK$\mathrm{M} \zeta$, which is activated by PDK1 during LTP maintenance or late LTP (L-LTP). Consistent phosphorylation by $\mathrm{PKM} \zeta$ even without second messengers increases and maintains the amount of active AMPARs at the synapse to sustain LTP.

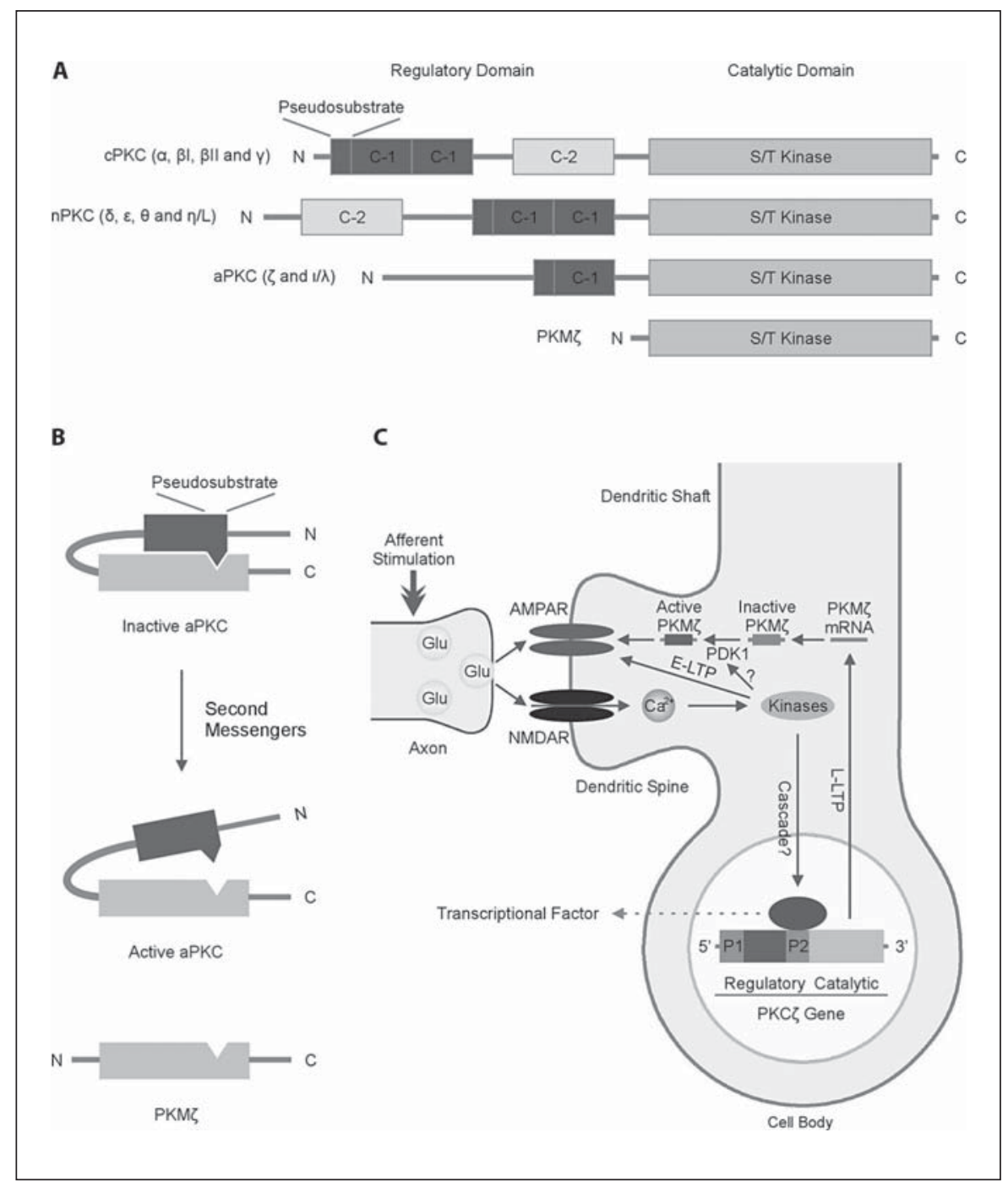

\section{LTP Induction}

The profile of induction and maintenance of LTP is becoming clear. Learning or other afferent stimulation activates the NMDARs and causes $\mathrm{Ca}^{2+}$ influx into the dendrite, which in turn activates some $\mathrm{Ca}^{2+}$-dependent kinases. Consequently, the conductance of receptor channels is enhanced to induce LTP expression or early LTP (E-LTP). On the other hand, the influx of $\mathrm{Ca}^{2+}$ also triggers an unknown signaling cascade toward the nucleus and initiates the internal promoter of the $\mathrm{PKC} \zeta$ gene to produce $\mathrm{PKM} \zeta \mathrm{mRNA}$. The $\mathrm{PKM} \zeta \mathrm{mRNA}$ is actively transported to dendrites and translated to produce PKM $\zeta$, which is activated by PDK1 during LTP maintenance or late LTP (L-LTP) (fig. 3C). The consistent second messenger-independent phosphorylation by PKM $\zeta$ increases and maintains the amount of active AMPARs at the synapse [91]. Although both GluR1 and GluR2 Ctermini are PKM $\zeta$ substrates in vitro [90], it would be more reasonable to propose that $\mathrm{PKM} \zeta$ phosphorylates some receptor-associated protein to regulate AMPAR trafficking, instead of directly modifying the receptor itself to change channel characteristics. Continuing to investigate possible candidates for $\mathrm{PKM} \zeta$ substrates is important for uncovering the roles of PKM $\zeta$ in the maintenance of synaptic plasticity.

\section{Atypical PKCs and LTP}

Coincidently, both $\mathrm{PKC} / / \lambda$ and $\mathrm{PKM} \zeta$, but not $\mathrm{PKC} \zeta$, are expressed in the mammalian brain at a high level, especially in the hippocampus [92]. $\mathrm{PKC \imath} / \lambda$ and $\mathrm{PKM} \zeta$ 
have a similar pattern of distribution in the human brain and both are activated after tetanization $[85,86,93]$. In addition, the catalytic domains of $\mathrm{PKC} / \lambda$ and $\mathrm{PKM} \zeta$ are almost identical. The PKM $\zeta$ inhibitors chelerythrine and ZIP also theoretically inhibit other aPKCs $[23,87]$. Therefore, results concerning $\mathrm{PKM} \zeta$ cannot exclude $\mathrm{PKC \iota} / \lambda$ involvement in synaptic plasticity. Moreover, it is possible that $\mathrm{PKC \iota} / \lambda$ plays a similar role as $\mathrm{PKM} \zeta$ does before the expression of $\mathrm{PKM} \zeta$ is promoted by afferent stimulation. It is also possible that $\mathrm{PKC} / / \lambda$ and $\mathrm{PKM} \zeta$ possess roles at different sites within the cells, because activated $\mathrm{PKC} / \lambda$ is bound to the cell membrane, whereas $\mathrm{PKM} \zeta$ is mainly located in the cytosol, due to its lack of a regulatory region. Application of chelerythrine, an aPKC inhibitor, and a dominant negative inhibitory form, PKM $\zeta-K 281 \mathrm{~W}$, also completely eliminated induction of LTP [87]. This would suggest that full-length $\mathrm{PKC} / \lambda$ might be involved in LTP induction. If so, phosphorylation by $\mathrm{PKC} / \lambda$ may be necessary for LTP induction, whereas later PKM $\zeta$ is expressed in dendrites and maintains LTP. In addition, a cytoplasmic and membrane-associated protein named p62 interacts with the pseudosubstrate region in the regulatory N-terminus of aPKC but not classic PKCs [94, 95]. By binding aPKC, p62 serves as a scaffold protein to recruit substrates to the kinase. This suggests to us that p62 might be involved in the regulation of synaptic plasticity through its interaction with $\mathrm{PKC \imath} / \lambda$.

\section{Ubiquitination and Receptor Endocytosis}

Ubiquitin has 76 amino acids and belongs to a family of small proteins highly conserved in structure. Ubiquitination, the attachment of a single ubiquitin or a polymeric ubiquitin chain to a protein, can regulate the proteins in many different ways. The prototypical function of ubiquitination is proteolysis through proteasomal pathway. Later, numerous studies revealed that ubiquitination also plays important roles in many other pathways beyond proteolysis $[96,97]$, such as protein location, activity, etc. The potential functions of the ubiquitin proteasome system (UPS) in synaptic strength have been investigated widely in many species including Caenorhabditis elegans, Aplysia, Drosophila, and mammal [98-104]. Surprisingly, UPS regulates the abundance of both presynaptic and postsynaptic proteins $[102,105]$ to exert multiple roles in synaptic development, presynaptic function and neurotransmitter release, alternation of postsynaptic density (PSD) and plasticity, spine growth and stability [106]. Here, we will focus on the recent progress in understanding ubiquitination as related to AMPAR trafficking and synaptic plasticity.

Protein Modifications and Interacting Proteins of AMPAR
As mentioned above, trafficking of AMPARs to and away from the postsynaptic membrane is the molecular basis for the change of synaptic strength. The amount of AMPARs at the synapse is regulated through exocytosis and endocytosis mediated by clathrin-coated vesicles [61, $107,108]$. The disruption of components of clathrin-coated vesicles such as dynamin and huntingtin-interacting protein 1 (HIP1) resulted in neurological deficits and a decrease of AMPAR trafficking [107, 109]. Recent studies reveal the UPS plays important roles for AMPAR endocytosis $[105,110]$, which is critical for LTD [61], induced by treatment of receptor agonists such as NMDA or hormones such as insulin [108]. Ubiquitination also was reported to play important roles in hippocampal LTP, but the detailed mechanism remains unknown [111]. Theoretically, the substrates of ubiquitination could be either the glutamate receptors themselves or receptor-associated proteins [110]. So far, no evidence of direct ubiquitination of AMPAR in mammals has been reported. However, GLR-1, the ortholog of mammalian GluR1 subunit in C. elegans, can be ubiquitinated in the intracellular Cterminus. The ubiquitination site (LxEFxYK/RSRxD/ EA $\underline{\text { ) }}$ is conserved in all mammalian AMPAR subunits and shares homology with the ubiquitin/endocytic signal of yeast proteins Ste2P and Ste6P [60, 99]. These findings suggest that ubiquitination of GLR-1 may mediate the synaptic strength and GLR-1-containing synapses through regulating the amount of receptor at the synapse in a clathrin adaptin protein (AP180)-dependent manner [99]. Interestingly, ubiquitination of KEL-8, a neuronal protein localized adjacent to GLR-1 on the postsynaptic membrane, is necessary for proteolysis of GLR-1 receptors and may regulate GluRs localization and signaling in postmitotic neurons [112].

In response to the synaptic activity, the PSD proteins, including some postsynaptic scaffolds, become highly ubiquitinated and those alterations, in turn, change downstream effectors like cyclic AMP (cAMP) response element-binding protein (CREB) and ERK-MAPK [105]. In particular, PSD-95, a major PSD scaffolding protein, mediates synaptic plasticity by anchoring NMDARs and AMPARs to the neuronal cytoskeleton or other receptorassociated proteins [113]. In response to NMDAR activation, PSD-95 is ubiquitinated and removed from the synaptic sites by UPS $[114,115]$. This results in a decrease of AMPAR expression in the synaptic surface during synaptic plasticity. Interestingly, $\beta$-amyloid $(A \beta)$, a peptide that is derived from amyloid precursor protein (APP) in neurons and widely believed to underlie the pathophysiology of Alzheimer's disease, can drive AMPAR endocy- 
tosis and cause loss of dendritic spines and inhibit hippocampal LTP $[116,117]$.

Following endocytosis, AMPARs in the early endosome are sorted via two different pathways. They are either recycled back to the cell surface or degraded through the lysosome, depending on the activations of NMDARs and AMPARs. With NMDAR activity stimulated by glutamate, AMPARs are internalized in a $\mathrm{Ca}^{2+}$-dependent manner, dephosphorylated by protein phosphatases, rephosphorylated by PKA, and at last rapidly reinserted in the synaptic membrane via recycling endosomes. On the other hand, without NMDAR activity, AMPARs are internalized in a $\mathrm{Ca}^{2+}$-independent manner, and then targeted to the lysosomes for degradation via late endosomes [59]. Consistently, in response to AMPA stimulation, internalized AMPARs enter the recycling system and reappear on the surface quickly, whereas in response to insulin treatment, internalized AMPARs are diverted into a distinct compartment, a non-recycling pathway [60]. Those reinserted AMPARs are a very important source of receptors for LTP expression [118]. The recycling endosomes and vesicles are also merged into spines to promote and maintain the growth of spines induced by synaptic plasticity $[48,119]$. Interestingly, chemically induced LTP (chemLTP) can drive strong exocytosis of AMPARs, but with a small loss of NMDARs on the spine surface. In addition, spines grow larger before collecting AMPARs on their surface [120]. So it is possible that recruitment of AMPARs to the spine surface requires accumulation of certain spine components, specifically, tethering proteins at the spine site.

\section{AMPAR-Interacting Proteins in Receptor Trafficking}

Unquestionably, the localization and trafficking of AMPARs are both an extremely complicated and highly regulated process. Many proteins interact with different AMPAR subunits to regulate receptor trafficking $[7,121$, 122]. We will discuss some of the more critical proteins.

\section{GluR1-Interacting Proteins}

Synapse-associated protein 97 (SAP97) is the first protein reported to directly interact with GluR1 subunit [123]. This PDZ-containing protein belongs to a protein family named synapse-associated protein (SAP) and other family members include some NMDAR subunit-interacting proteins such as SAP90 (PSD95), chapsyn110 (PSD93) and SAP102 [121]. SAP97 has three PDZ domains and interacts with the very C-terminal of GluR1 with its second PDZ domain [123, 124]. SAP highly accumulates at GluR1-containing synapses, so SAP may serve as an anchoring molecule to help GluR1 reside stably in the synaptic surface [125]. The interaction between SAP97 and GluR1 first occurs in the receptor secretory pathway and is essential for the transport of the receptor from the endoplasmic reticulum to the cis face of Golgi apparatus (fig. 2A) [49]. The interaction of SAP97 with A kinase anchoring protein 79 (AKAP79) can target PKA to GluR1 for S845 phosphorylation and may be involved in the LTD induction [126, 127]. Phosphorylation by CaMKII regulates SAP97 targeting and interaction with NMDAR subunit NR2A [128, 129]. Interestingly, PDZ domain-containing proteins including SAP 97 are widely believed to play critical roles in AMPAR trafficking and LTP expression $[46,74]$. However, transgenic mice lacking the C-terminal PDZ-binding site of GluR1 show normal GluR1 synaptic localization and unimpaired hippocampal CA1 LTP [130].

Proteins $4.1 \mathrm{G} / \mathrm{N}$ are the other GluR1-interacting proteins [54]. They belong to a family of multifunctional cytoskeletal components $(4.1 \mathrm{~B} / \mathrm{G} / \mathrm{N} / \mathrm{R})$ originally isolated from erythrocytes and are essential for assembly and maintenance of the actin cytoskeleton. $4.1 \mathrm{~N}$ is enriched in synapses, whereas $4.1 \mathrm{G}$ is expressed in all cells [131]. Both $4.1 \mathrm{G}$ and $4.1 \mathrm{~N}$ bind to the intracellular membrane proximal region of GluR1. Particularly, $4.1 \mathrm{~N}$ interacts with GluR1 in vivo and colocalizes with AMPARs at excitatory synapses. Destruction of actin filaments in cultured cortical neurons significantly decreases GluR1 surface expression. Taken together, $4.1 \mathrm{G} / \mathrm{N}$ may serve as adapters to link GluR1 to the actin cytoskeleton [54]. The actin filaments, but not microtubules, are abundant in the dendritic spine [132]. These observations suggest that GluR1-containing AMPARs are delivered to synapses along actin filaments (fig. 2B). Interestingly, GluR4 also has a 4.1 binding site and the 4.1 proteins may affect GluR4 trafficking and localization in a manner similar to that found for GluR1 [133].

\section{GluR2-Interacting Proteins}

GRIP/ABP binds to the C-terminus of GluR2/3 via PDZ domains. GRIP contains seven PDZ domains with a molecular weight of $130 \mathrm{kDa}$. Its fourth and fifth PDZ domains bind the very C-terminal motif of GluR2/3 (ESVKI) [134]. ABP is a close relative of GRIP and has two splice variants: the short $98-\mathrm{kDa}$ isoform named ABP-S has six PDZ domains and the third, fifth and sixth mediate binding to GluR2/3; the long $130-\mathrm{kDa}$ isoform named ABP-L or GRIP2 has seven PDZ domains [135]. 
Both GRIP and ABP are ubiquitously expressed in the CNS and enriched in the PSD, but GRIP can be detected before the emergence of AMPARs during embryonic development, whereas the expression pattern of $A B P$ resembles AMPARs [136]. The function of GRIP has not been fully elucidated, but its multiple PDZ domains may endow the protein to function as an adapter. In fact, several proteins can bind to its PDZ domains other than the fourth and the fifth [137]. Some other proteins may regulate AMPARs signaling and trafficking via GRIP. For example, GRIP-associated protein-1 (GRASP-1) is a rasGEF in neurons and associated with GRIP and AMPARs in vivo. Overexpression of GRASP-1 in cultured neurons causes a down-regulation of synaptic targeting of AMPARs [137]. Through GRIP, AMPARs are linked to activity-dependent Ras signaling and trafficking events and the caspase pathway [138]. In another case, both of the Eph receptors, a family of receptor tyrosine kinases, and their ephrin ligands, bind to the sixth and seventh PDZ domains of GRIP [139] and the interaction that may be involved in neurite extension and axonal guidance [140], and recruitment of intracellular GRIPs to membrane lipid rafts [141]. The interactions of GRIP with kinesin heavy chain [53] and microtubule-associated protein (MAP)-1B light chain (LC) [142] may link AMPAR to microtubular motor protein trafficking. Liprin- $\alpha$ interacts with GRIP and is necessary for AMPAR targeting [143]. Liprin- $\alpha$ can also can associate with KIF1A, another member of the kinesin superfamily of molecular motors [144]. In addition, interaction between liprin- $\alpha$ and GIT1 is also necessary for AMPAR targeting [145]. Taken together, AMPAR trafficking along the microtubular cytoskeleton in the dendrite is mediated by interaction between GRIP and several microtubular motor proteins (fig. 2A).

Protein interacting with $\mathrm{C}$ kinase (PICK1) has a BAR (Bin/amphiphysin/Rvs) domain and a PDZ domain, through which the dimer of PICK1 could bind to the Cterminus of GluR2 [146] and the catalytic domain of PKC $\alpha$ [147]. So, PICK1 may target the AMPARs to an active PKC $\alpha$ [148]. S880 phosphorylation of GluR2 by PKC upon phorbol ester (TPA) induction releases GluR2-containing AMPARs from GRIP1 binding, and increases receptor binding to PICK1. As a result, more PICK1 traffic to synapses and GluR2-containing AMPARs are internalized rapidly to result in cerebellar and hippocampal LTD $[78,79]$. T876 phosphorylation has the similar effects on GluR2 binding to ABP/GRIP and PICK1 [36]. An interesting model may explain the functions of PICK1 and GRIP/ABP in GluR2-containing AMPAR internal- ization. PICK1 BAR domain interacts with its PDZ domain and also interacts with GRIP/ABP linker II region. Binding to GluR2 or PKC $\alpha$ interrupts the intramolecular interaction and facilitates the intermolecular interaction of PICK1 BAR domain with GRIP/ABP linker II region. Then PKC $\alpha$ phosphorylates S880 of GluR2 and the phosphorylated GluR2 is released from GRIP/ABP to bind to PICK1. Finally, the PICK1 BAR domain directs receptor internalization [149]. PICK1 may also be involved in the formation of extrasynaptic membrane pools of GluR2containing AMPAR which later could be targeted to the synaptic membrane via lateral trafficking [6]. The interaction between PICK1 and GluR2 is also necessary for receptor exit from the ER (fig. 2B) [51, 149]. Considering PICK1 interacts with more than a dozen proteins besides GluR2, PKC $\alpha$, and GRIP/ABP [150], the AMPAR trafficking regulated by GRIP is expected to be more complicated. A recent study revealed that the neuronal endosomal protein NEEP21 may be involved in the GluR2containing AMPAR sorting and reinsertion into the cell surface by binding with GRIP and GluR2 subunit [151].

The interaction between ATPase $N$-ethylmaleimidesensitive fusion protein (NSF) and AMPAR subunit GluR2 was first detected by using the yeast two-hybrid screen $[152,153]$. A region in the GluR2 C-terminus (KRMKVAKNPQ) is responsible for NSF binding with asparagine 851 playing an essential role [153]. NSF is a well-known multihomomeric ATPase that plays a central role in docking and fusion of synaptic vesicles [154]. Perfusion of a synthetic peptide pep2 $\mathrm{m}$ mimicking the NSFbinding site on GluR2 to postsynaptic sites partially blocked synaptic transmission [155]. Therefore, NSF may play a role in the regulated delivery of GluR2-containing AMPARs from the postsynaptic surface to the lysosome during LTD [47]. Overexpression of NSF in cultured hippocampal neurons caused a down-regulation in surface expression of AMPARs, but the total AMPAR expression was unaffected [156]. Interestingly, both PICK1 and NSF are necessary for calcium-permeable AMPAR plasticity (CARP), and dynamically exchange AMPARs lacking GluR2 with GluR2-containing AMPARs in the synapse during CARP to mediate the calcium permeability of AMPAR [6].

AP2 belongs to the family of assembly particles and other members include AP1 and AP3. Particularly, AP2 complex, a well-characterized clathrin adapter involved in endocytosis from the cell surface, consists of four subunits: $\alpha, \beta, \sigma$ and $\mu$ adaptins. Clathrin adapters are essential for endocytosis by linking membrane proteins to clathrin and facilitating assembly of clathrin coats. There- 
fore, association of clathrin adapters to the cytoplasmic domains of receptors is a key to promote receptor endocytosis [157]. Activity-dependent AMPAR internalization occurs via dynamin-dependent clathrin-coated vesicles [61, 107, 108]. Interestingly, AP2 associates with GluR2 in almost the same region as the NSF-binding site. In fact, application of pep2 $\mathrm{m}$ blocks both AP2 and NSF binding to GluR2 [155]. Although sharing the same binding site on GluR2, AP2 and NSF play distinct roles in the maintenance and removal of AMPARs at the synapse.

\section{Other AMPAR-Interacting Proteins}

Transmembrane AMPAR regulatory protein (TARP) family has four members: $\gamma-2$ (or stargazin), $\gamma-3, \gamma-4$ and $\gamma-8$. Stargazin, the prototypical TARP, is the first identified transmembrane interactor of AMPARs $[5,158]$. Stargazin is mutated in the stargazer mice that show a phenotype of the absence epilepsy and cerebellar ataxia, which results from the lack of functional AMPAR channels in cerebellar granule cells [158-160]. These four proteins may function as the auxiliary components of neuronal AMPARs $[5,161]$ and are spatiotemporally expressed during differentiation and development in the CNS. $\gamma-4$ is dominant during early development; stargazin is the only expressed TARP in cerebellar granule cells, but lacking from the hippocampal CA1 region; $\gamma-8$ is highly expressed allover the hippocampus [162]. Different distribution of TARPs would implicate differential and developmental control of activity-dependent trafficking affairs. Stargazin is a four-transmembrane protein and targets AMPARs to the granule cell surface [162]. The intracellular C-terminus of stargazin binds to some PDZ proteins including PSD-95 to mediate synaptic trafficking and clustering of AMPARs [158]. Stargazin also can be phosphorylated in an activity-dependent pattern to regulate hippocampal synaptic strength $[163,164]$. In addition, stargazin controls AMPAR channel gating by slowing glutamate-induced AMPAR deactivation and desensitization, and enhancing the channel conductance $[163,165]$. Both extracellular and intracellular regions of stargazin interact with AMPARs [162] and the interaction may be direct because immunoprecipitation of stargazin also pulled down other AMPAR-interacting proteins [5], although which domain of GluRs is responsible for stargazin binding remains unknown. A recent study revealed that a point mutation in the glutamate-binding region of GluR1 destroys stargazin's effects on receptor trafficking and channel gating. This finding suggests that the glutamate-binding domain of AMPARs could be the extracellular binding site for TARPs [166].
Soluble NSF attachment protein (SNAP) has three forms: $\alpha, \beta$ and $\gamma$, and is critical in membrane fusion. Particularly, $\alpha$ - and $\beta$-SNAPs interact with the $\mathrm{C}$-terminus of the GluR2 subunit [167]. As the name indicated, SNAPs can bind NSF [168], but they associate with AMPARs independently with an increase of the amount of AMPARs binding SNAP in the presence of NSF because AMPARs can recruit more SNAPs indirectly via NSF [167]. SNAP is another AMPAR interactor involved in vesicle budding and fusion beside NSF and may play a role in regulating synaptic expression of AMPARs through a direct association with receptors $[169,170]$. In addition, SNAPs and NSF can disassemble the GluR2-PICK1 complex to mediate AMPAR surface expression [171].

Lyn is a Src-family non-receptor protein tyrosine kinase and is highly expressed in CNS. About 1-2\% of Lyn in the cerebellum associates with GluR2-containing or GluR3-containing AMPARs via its Src homology region consisting of $\mathrm{SH} 2$ and $\mathrm{SH} 3$ domains [172]. Lyn is activated by AMPAR in a $\mathrm{Ca}^{2+}$ - and $\mathrm{Na}^{+}$-independent manner and promotes the MAPK-signaling cascade to initiate expression of brain-derived neurotropic factor (BDNF), which is involved in the regulation of synaptic plasticity besides in neuronal survival and differentiation [173176]. Therefore, in addition to synaptic transmission via cation influx, AMPARs may be directly involved in mediating intracellular signal from the cell surface to the nucleus through the Lyn-MAPK cascade and mediate synaptic plasticity by regulating BDNF expression [172].

LIN-10 is a membrane-associated protein that mediates localization of GLR-1 in C. elegans [177]. Its human ortholog, mLin-10, directly associates with GluR1 and GluR2 subunits through a PDZ domain-dependent mechanism and mediates the receptor trafficking [178]. $\mathrm{X} 11 \mathrm{~L}$, a homolog of mLin-10, can bind the $\mathrm{p} 65$ subunit of NF- $\kappa B$ to regulate $A \beta$ production in neurons and may indicate a novel means to control the progression of Alzheimer's disease [179]. In addition, GluR1 subunit was detected in association with the guanine-nucleotidebinding protein $\left(\mathrm{G}_{\mathrm{il}}\right)$ and stimulation with AMPA can regulate $\mathrm{G}_{\mathrm{il}}$ function in a $\mathrm{Ca}^{2+}$ - and $\mathrm{Na}^{+}$-independent manner [180]. This suggests that AMPAR could exert a metabotropic function besides the ion channel.

\section{Future Directions}

Cumulative studies reveal that AMPAR-interacting molecules play critical roles in AMPAR-related synaptic plasticity. Some interacting molecules regulate posttrans- 
lational modification of the receptors, while others mediate receptor trafficking, cellular localization and signal transduction cascades. Undoubtedly, AMPAR posttranslational modifications and AMPAR-associated proteins are the key to mediate receptor trafficking, which is the underlying molecular mechanism for synaptic plasticity. Despite more than two decades of intense research [58], the complete mechanism of AMPAR trafficking is not clear. For proteins whose binding sites on AMPAR subunits are determined such as $4.1 \mathrm{~N}$, SAP97, GRIP/ABP, PICK1, AP2, NSF and TARPs, their functions in AMPAR trafficking are basically understood (fig. 4). For those proteins whose binding sites on the AMPAR subunit remain unknown, continued efforts to characterize the binding sites will shed light on their functions in the regulation of synaptic strength [122]. Unquestionably, more AMPAR-interacting proteins will be discovered and will

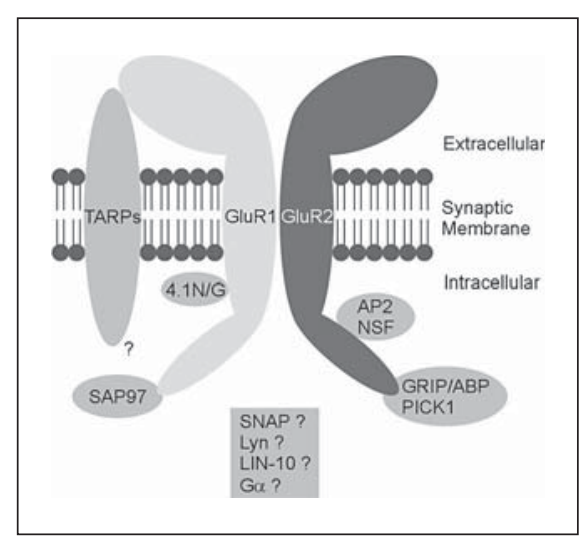

Fig. 4. Interactions between AMPARs and associated proteins. 4.1G/N and SAP97 interact with the GluR1 subunit, whereas AP2, NSF, GRIP/ABP and PICK1 interact with the GluR2 subunit. Both extracellular and intracellular regions of TARPs interact with AMPARs, but the intracellular binding site is unknown. Other AMPAR-associated proteins include Lyn, LIN-10 and G $\alpha$, but the binding sites are unclear. allow us to develop a more complete picture of AMPAR interactions. Those AMPAR-associated proteins could be newly discovered or some existing proteins with novel functions in plasticity. As discussed previously, p62, the aPKC adapter, is a possible AMPAR-associated protein. p62 is a cytoplasmic and membrane-associated protein with a molecular weight of about $62 \mathrm{kDa}$. It is also named zeta protein kinase $\mathrm{C}$ interacting protein (ZIP, different from ZIP inhibitor of $\mathrm{PKM} \zeta$ ) and was initially identified as a phosphotyrosine-independent ligand of the Src homology 2 (SH2) domain of p56 lck [94]. The p62 protein possesses 6 domains, which endow it with the ability to associate with many other proteins (fig. 5): a PB1 domain for aPKC binding, a ZZ-type Zinc finger domain for binding aPKC substrates [95, 181-183], a tumor necrosis factor (TNF) receptor-associated factor 6 (TRAF6)-binding domain, two PEST domains for proteolytic recognition, and a ubiquitin-associated (UBA) domain. p62 is concentrated in hippocampus [95]. Based on its specific structure, p62 serves as a scaffold to recruit substrates of aPKC through its PB1 domain and ZZ-type finger domain [184]. In addition, p62 also functions as an adapter protein in the process of polyubiquitination of many proteins, especially membrane-associated receptors, and specifically binds proteins with K63-polyubiquitin attached through its C-terminal UBA domain, which initiates ubiquitination-mediated receptor endocytosis [185]. Furthermore, p62 may function as an intracellular shuttling factor [186]. Interestingly, the p62 knockout mice exhibit impaired spatial learning and memory, a hippocampal-dependent process [M.W. Wooten, unpubl. data]. Defective spatial learning and memory often correlates with impaired hippocampal LTP. These results suggest that p62 may play a yet to be defined role in regulating synaptic transmission.

Theoretically, $\mathrm{PKC \imath} / \lambda$ may play an important role for early expression of LTP (E-LTP), whereas PKM $\zeta$ is essential for LTP maintenance $[23,87]$. If so, p62 could target
Fig. 5. p62 primary structure. p62 possesses 6 domains: a PB1 domain consisting of a SH2-binding site and an aPKC interaction domain (AID), a ZZ-type finger domain binds aPKC substrates, a tumor necrosis factor (TNF) receptor-associated factor 6 (TRAF6)-binding domain, two PEST domains for proteolytic recognition, and a ubiquitin-associated (UBA) domain.

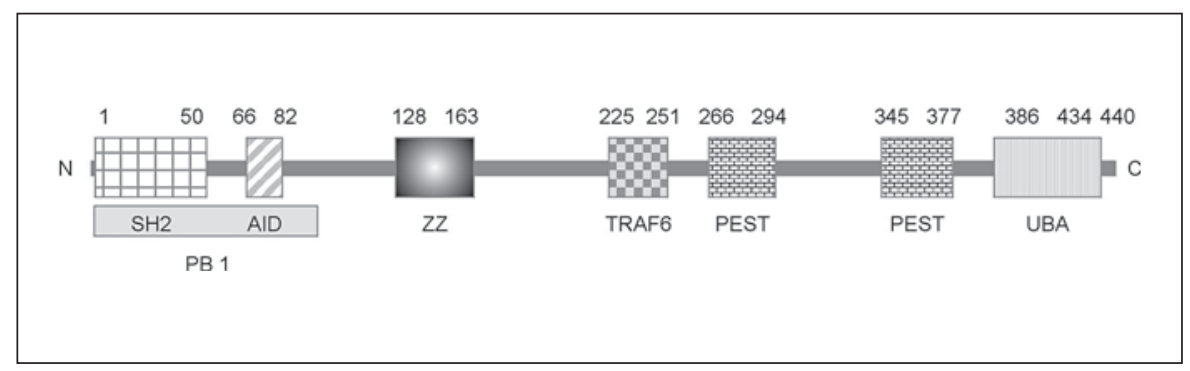


potential substrates to $\mathrm{PKC} / \lambda$ to mediate $\mathrm{E}-\mathrm{LTP}$ through aPKC-dependent phosphorylation. In addition, p62 could also serve as an adapter to facilitate the ubiquitination at the PSD to mediate endocytosis of the receptor itself or of some receptor-associated proteins [110]. Investigating the possible roles of $\mathrm{p} 62$ in synaptic plasticity may help to uncover additional information on the molecular and cellular mechanisms of synaptic plasticity.

Neurotrophins have been shown to modulate numerous aspects of synaptic transmission and neural plasticity [187]. Recently it has been shown that BDNF can regulate the expression and synaptic delivery of AMPAR subunits [176]. In this scenario, BDNF activates both PKC and CaMKII to phosphorylate S831 and possibly S818 in the C-terminal tail of GluR1, leading to synaptic incorporation of GluR1. Also it is possible that BDNF may induce the phosphorylation of a regulatory protein that facilitates insertion or delivery of the GluR1 subunit into the synapse. Possible regulation of LTP by BDNF/PKC and p62 as it relates to learning and memory is currently underway in our laboratory.

\section{Acknowledgements}

The authors thank Jacek Wower and Elaine S. Coleman for helpful comments, and Catherine Wernette for editorial assistance. This research was supported by NIH grant NS33661 (to M.W.W.).

\section{References}

$\checkmark 1$ Wisden W, Seeburg PH: Mammalian ionotropic glutamate receptors. Curr Opin Neurobiol 1993;3:291-298.

2 Hollmann M, Heinemann S: Cloned glutamate receptors. Annu Rev Neurosci 1994;17: $31-108$.

-3 Dingledine R, Borges K, Bowie D, Traynelis SF: The glutamate receptor ion channels. Pharmacol Rev 1999;51:7-61.

-4 Collingridge GL, Isaac JT, Wang YT: Receptor trafficking and synaptic plasticity. Nat Rev Neurosci 2004;5:952-962.

5 Fukata Y, Tzingounis AV, Trinidad JC, Fukata M, Burlingame AL, Nicoll RA, Bredt DS: Molecular constituents of neuronal AMPA receptors. J Cell Biol 2005;169:399404.

-6 Gardner SM, Takamiya K, Xia J, Suh JG, Johnson R, Yu S, Huganir RL: Calcium-permeable AMPA receptor plasticity is mediated by subunit-specific interactions with PICK1 and NSF. Neuron 2005;45:903-915.

$\checkmark 7$ Palmer CL, Cotton L, Henley JM: The molecular pharmacology and cell biology of $\alpha$ amino-3-hydroxy-5-methyl-4-isoxazolepropionic acid receptors. Pharmacol Rev 2005;57:253-277.

8 Monyer H, Seeburg PH, Wisden W: Glutamate-operated channels: developmentally early and mature forms arise by alternative splicing. Neuron 1991;6:779-810.

-9 Gallo V, Linus MU, Hayes WP, Vyklicky L Jr, Winters CA, Buonanno A: Molecular cloning and developmental analysis of a new glutamate receptor subunit isoform in cerebellum. J Neurosci 1992;12:1010-1023.

10 Köhler M, Kornau H-C, Seeburg PH: The organization of the gene for the functionally dominant $\alpha$-amino-3-hydroxy-5-methylisoxazole-4-propionic acid receptor subunit GluR-B. J Biol Chem 1994;269:17367-17370.
11 Wenthold RJ, Petralia RS, Blahos J II, Niedzielski AS: Evidence for multiple AMPA receptor complexes in hippocampal CA1/ CA2 neurons. J Neurosci 1996; 16:19821989.

12 Swanson GT, Kamboj SK, Cull-Candy SG: Single-channel properties of recombinant AMPA receptors depend on RNA editing splice variation and subunit composition. J Neurosci 1997; 17:58-69.

13 Lomeli H, Mosbacher J, Melcher T, Hoger T, Geiger JR, Kuner T, Monyer H, Higuchi M, Bach A, Seeburg PH: Control of kinetic properties of AMPA receptor channels by nuclear RNA editing. Science 1994;266:1709-1713.

14 Bass BL, Nishidura K, Keller W, Seeburg PH, Emeson RB, O'Connell MA, Samuel CE, Herbert A: A standardized nomenclature for adenosine deaminases that act on RNA. RNA 1997;3:947-949.

15 Higuchi M, Maas S, Single FN, Hartner J, Rozov A, Burnashev N, Feldmeyer D, Sprengel R, Seeburg PH: Point mutation in an AMPA receptor gene rescues lethality in mice deficient in the RNA-editing enzyme ADAR2. Nature 2000;406:78-81.

16 Ohman M, Kallman AM, Bass BL: In vitro analysis of the binding of ADAR2 to the premRNA encoding the GluR-B R/G site. RNA 2000;6:687-697.

17 Mayer ML: Glutamate receptor ion channel. Curr Opin Neurobiol 2005;15:282-288.

18 Bliss TVP, Lømo T: Long-lasting potentiation of synaptic transmission in the dentate area of the anaesthetized rabbit following stimulation of the perforant path. J Physiol 1973;232:331-356.

19 Bliss TVP, Collingridge GL: A synaptic model of memory: long-term potentiation in the hippocampus. Nature 1993;361:31-39.
20 Kandel ER: Genes, synapses, and long-term memory. J Cell Physiol 1997;173:124-125.

21 Malinow R, Malenka RC: AMPA receptors trafficking and synaptic plasticity. Annu Rev Neurosci 2002;25:103-126.

22 Lynch MA: Long-term potentiation and memory. Physiol Rev 2004;84:87-136.

23 Pastalkova E, Serrano P, Pinkhasova D, Wallace E, Fenton AA, Sacktor TC: Storage of spatial information by the maintenance mechanism of LTP. Science 2006;313:11411144

24 Malenka RC: Synaptic plasticity and AMPA receptor trafficking. Ann NY Acad Sci 2003; 1003:1-11.

25 Malenka RC, Bear MF: LTP and LTD: an embarrassment of riches. Neuron 2004;44:521.

26 Malenka RC: Synaptic plasticity in the hippocampus: LTP and LTD. Cell 1994;78:535538.

27 Malenka RC, Nicoll RA: Long-term potentiation - a decade of progress. Science 1999; 285:1870-1874.

$>28$ Frey U, Huang YY, Kandel ER: Effects of cAMP simulate a late stage of LTP in hippocampal CA1 neurons. Science 1993;260: 1661-1664.

29 Esteban JA: AMPA receptor trafficking: a road map for synaptic plasticity. Mol Interv 2003;3:375-385.

30 Roche KW, O’Brien RJ, Mammen AL, Bernhardt J, Huganir RL: Characterization of multiple phosphorylation sites on the AMPA receptor GluR1 subunit. Neuron 1996;16: 1179-1188.

-31 Boehm J, Malinow R: AMPA receptor phosphorylation during synaptic plasticity. Biochem Soc Trans 2005;33:1354-1356. 
-32 Boehm J, Kang MG, Johnson RC, Esteban J, Huganir RL, Malinow R: Synaptic incorporation of AMPA receptors during LTP is controlled by a PKC phosphorylation site on GluR1. Neuron 2006;51:213-225.

- 33 Atkins CM, Selcher JC, Petraitis JJ, Trzaskos JM, Sweatt JD: The MAPK cascade is required for mammalian associative learning. Nat Neurosci 1998;1:602-609.

- 34 Opazo P, Watabe AM, Grant SG, O’Dell TJ: Phosphatidylinositol 3-kinase regulates the induction of long-term potentiation through extracellular signal-related kinase-independent mechanisms. J Neurosci 2003;23:36793688.

- 35 Stellwagen D, Beattie EC, Seo JY, Malenka RC: Differential regulation of AMPA receptors and GABA receptors trafficking by tumor necrosis factor- $\alpha$. J Neurosci 2005;25: 3219-3228.

36 Hayashi T, Huganir RL: Tyrosine phosphorylation and regulation of the AMPA receptor by SRC family tyrosine kinases. J Neurosci 2004;24:6152-6160.

37 Lee HK, Barbarosie M, Kameyama K, Bear MF, Huganir RL: Regulation of distinct AMPA receptor phosphorylation sites during bidirectional synaptic plasticity. Nature 2000;405:955-959.

- 38 Sheng M, Kim MJ: Postsynaptic signaling and plasticity mechanisms. Science 2002; 298:776-780

-39 Thomas GM, Huganir RL: MAPK cascade signaling and synaptic plasticity. Nat Rev Neurosci 2004;5:173-183.

40 Matus A: Actin-based plasticity in dendritic spines. Science 2000;290:754-758.

41 Fukazawa Y, Saitoh Y, Ozawa F, Ohta Y, Mizuno K, Inokuchi K: Hippocampal LTP is accompanied by enhanced F-actin content within the dendritic spine that is essential for late LTP maintenance in vivo. Neuron 2003; 38:447-460.

42 Zamanillo D, Sprengel R, Hvalby O, Jensen V, Burnashev N, Rozov A, Kaiser KM, Koster HJ, Borchardt T, Worley P, Lubke J, Frotscher M, Kelly PH, Sommer B, Andersen P, Seeburg PH, Sakmann B: Importance of AMPA receptors for hippocampal synaptic plasticity but not for spatial learning. Science 1999; 284:1805-1811.

-43 Reisel D, Bannerman DM, Schmitt WB, Deason RM, Flint J, Borchardt T, Seeburg PH, Rawlins JNP: Spatial memory dissociations in mice lacking GluR1. Nat Neurosci 2002;5:868-873.

-44 Chan CS, Weeber EJ, Zong L, Fuchs E, Sweatt JD, Davis RL: $\beta_{1}$-Intergrins are required for hippocampal AMPA receptor-dependent synaptic transmission synaptic plasticity and working memory. J Neurosci 2006;26: 223-233.

45 Passafaro M, Piëch V, Sheng M: Subunit-specific temporal and spatial patterns of AMPA receptor exocytosis in hippocampal neurons. Nat Neurosci 2001;4:917-926.
46 Shi S, Hayashi Y, Esteban JA, Malinow R: Subunit-specific rules governing AMPA receptor trafficking to synapses in hippocampal pyramidal neurons. Cell 2001;105:331343.

47 Lee SH, Simonetta A, Sheng M: Subunit rules governing the sorting of internalized AMPA receptors in hippocampal neurons. Neuron 2004;43:221-236.

48 Kennedy MJ, Ehlers MD: Organelles and trafficking machinery for postsynaptic plasticity. Annu Rev Neurosci 2006;29:325-362.

49 Sans N, Racca C, Petralia RS, Wang YX, McCallum J, Wenthold RJ: Synapse-associated protein 97 selectively associates with a subset of AMPA receptors early in their biosynthetic pathway. J Neurosci 2001;21:7506-7516.

50 Rubio ME, Wenthold RJ: Calnexin and the immunoglobulin binding protein $(\mathrm{BiP}) \mathrm{co}$ immunoprecipitate with AMPA receptors. J Neurochem 1999;73:942-948.

51 Greger IH, Khatri L, Ziff EB: RNA editing at $\arg ^{607}$ controls AMPA receptor exit from the endoplasmic reticulum. Neuron 2002;30: 759-772.

52 Goldstein LS, Yang Z: Microtubule-based transport systems in neurons: the roles of kinesins and dyneins. Annu Rev Neurosci 2000;23:39-71.

53 Setou M, Seog DH, Tanaka Y Kanai Y Takei Y Kawagishi M, Hirokawa N: Glutamate-receptor-interacting protein GRIP1 directly steers kinesin to dendrites. Nature 2002;417: 83-87.

54 Shen L, Liang F, Walensky LD, Huganir RL: Regulation of AMPA receptor GluR1 subunit surface expression by a $4.1 \mathrm{~N}$-linked actin cytoskeletal association. J Neurosci 2000 20:7932-7940

55 Malinow R, Mainen ZF, Hayashi Y: LTP mechanisms: from silence to four-lane traffic. Curr Opin Neurobiol 2000;10:352-357.

-56 Shi S, Hayashi Y, Petralia RS, Zaman SH Wenthold RJ, Svoboda K, Malinow R: Rapid spine delivery and redistribution of AMPA receptors after synaptic NMDA receptor activation. Science 1999;284:1811-1815.

57 Adesnik H, Nicoll RA, England PM: Photoinactivation of native AMPA receptors reveals their real-time trafficking. Neuron 2005;48:977-985.

58 Lynch G, Baudry M: The biochemistry of memory: a new and specific hypothesis. Science 1984;224:1057-1063.

59 Ehlers MD: Reinsertion or degradation of AMPA receptors determined by activity-dependent endocytic sorting. Neuron 2000;28: 511-525.

60 Lin JW, Ju W, Foster K, Lee SH, Ahmadian G, Wyszynski M, Wang YT, Sheng M: Distinct molecular mechanisms and divergent endocytotic pathways of AMPA receptor internalization. Nat Neurosci 2000;3:12821290.
61 Carroll RC, Beattie EC, von Zastrow M, Malenka RC: Role of AMPA receptor endocytosis in synaptic plasticity. Nat Rev Neurosci 2001;2:315-324

-62 Sheng M, Lee SH: AMPA receptor trafficking and the control of synaptic transmission. Cell 2001;105:825-828

63 Barry MF, Ziff EB: Receptor trafficking and the plasticity of excitatory synapses. Curr Opin Neurobiol 2002;12:279-286.

64 Song I, Huganir RL: Regulation of AMPA receptors during synaptic plasticity. Trends Neurosci 2002;25:578-588.

65 Malinow R: AMPA receptor trafficking and long-term potentiation. Philos Trans R Soc Lond B Biol Sci 2003;358:707-714.

66 Sheng M, Lee SH: AMPA receptor trafficking and synaptic plasticity: major unanswered questions. Neurosci Res 2003;46: 127-134.

67 Rumpel S, LeDoux J, Zador A, Malinow R: Postsynaptic receptor trafficking underlying a form of associative learning. Science 2005;308:83-88.

68 Bredt DS, Nicoll RA: AMPA receptor trafficking at excitatory synapses. Neuron 2003; 40:361-379.

69 Armstrong N, Sun Y, Chen G-Q, Gouaux E: Structure of a glutamate receptor ligandbinding core in complex with kainate. Nature 1998;395:913-917.

70 Everts I, Villmann C, Hollmann M: N-Glycosylation is not a prerequisite for glutamate receptor ion channel function. Mol Pharmacol 1997;52:861-873.

71 Hayashi T, Rumbauth G, Huganir RL: Differential regulation of AMPA receptor subunit trafficking by palmitoylation of two distinct sites. Neuron 2005;47:709-723.

72 Mammen AL, Kameyama K, Roche KW, Huganir RL: Phosphorylation of the $\alpha$-amino-3-hydroxy-5-methylisoxazole-4-propionic acid receptor GluR1 subunit by calcium/calmodulin-dependent kinase II. J Biol Chem 1997;272:32528-32533.

73 Oh MC, Derkach VA, Guire ES, Soderling TR: Extrasynaptic membrane trafficking regulated by GluR2 Serine 845 phosphorylation primes AMPA receptors for long-term potentiation. J Biol Chem 2006;281:752-758.

-74 Hayashi Y, Shi SH, Esteban JA, Piccini A, Poncer JC, Malinow R: Driving AMPA receptors into synapses by LTP and CaMKII: requirement for GluR1 and PDZ domain interaction. Science 2000;287:2262-2267.

-75 Esteban JA, Shi SH, Wilson C, Nuriya M, Huganir RL, Malinow R: PKA phosphorylation of AMPA receptor subunits controls synaptic trafficking underlying plasticity. Nat Neurosci 2003;6:136-143.

76 Lee HK, Takamiya K, Han JS, Man H, Kim $\mathrm{CH}$, Rumbaugh G, Yu S, Ding L, He C, Petralia RS, Wenthold RJ, Gallagher M, Huganir RL: Phosphorylation of AMPA receptor GluR1 subunit is required for synaptic plasticity and retention of spatial memory. Cell 2003;112:631-643 
77 Chung HJ, Xia J, Scannevin RH, Zhang X, Huganir RL: Phosphorylation of the AMPA receptor subunit GluR2 differentially regulates its interaction with PDZ domain-containing proteins. J Neurosci 2000;20:72587267.

-78 Seidenman KJ, Steinberg JP, Huganir RL, Malinow R: Glutamate receptor subunit 2 serine 880 phosphorylation modulates synaptic transmission and mediates plasticity in CA1 pyramidal cells. J Neurosci 2003;23: 9220-9228.

79 Chung HJ, Steinberg JP, Huganir RL, Linden DJ: Requirement of AMPA receptor GluR2 phosphorylation for cerebellar long-term depression. Science 2003;300:1751-1755.

-80 McDonald BJ, Chung HJ, Huganir RL: Identification of protein kinase C phosphorylation sites within the AMPA receptor GluR2 subunit. Neuropharmacology 2001;41:672679.

81 Zhu JJ, Esteban JA, Hayashi Y, Malinow R: Postnatal synaptic potentiation: delivery of GluR4-containing AMPA receptors by spontaneous activity. Nat Neurosci 2000;3:10981106.

82 Correia SS, Duarte CB, Faro CJ, Pires EV, Carvalho AL: Protein kinase $\mathrm{C} \gamma$ associates directly with the GluR4 $\alpha$-amino-3-hydroxy-5-methyl-4-isoxazole propionate receptor subunit. J Biol Chem 2003;278:63076313.

83 Carvalho AL, Kameyama K, Huganir RL: Characterization of phosphorylation sites on the glutamate receptor 4 subunit of the AMPA receptors. J Neurosci 1999;19:47484754.

84 Newton AC: Protein kinase C: structural and spatial regulation by phosphorylation cofactors and macromolecular interactions. Chem Rev 2001;101:2353-2364.

-85 Sacktor TC, Osten P, Valsamis H, Jiang X, Naik MU, Sublette E: Persistent activation of the $\zeta$ isoforms of protein kinase $\mathrm{C}$ in the maintenance of long-term potentiation. Proc Natl Acad Sci USA 1993;90:8342-8346.

86 Hernandez AI, Blace N, Crary JF, Serrano PA, Leitges M, Libien JM, Weinstein G, Tcherapanov A, Sacktor TC: Protein kinase $M \zeta$ synthesis from a brain mRNA encoding an independent protein kinase $\mathrm{C} \zeta$ catalytic domain. J Biol Chem 2003;278:4030540316.

87 Ling DSF, Benardo LS, Serrano PA, Blace N, Kelly MT, Crary JF, Sacktor TC: Protein kinase $\mathrm{M} \zeta$ is necessary and sufficient for LTP maintenance. Nat Neurosci 2002;5:295296.

88 Serrano P, Yao Y, Sacktor TC: Persistent phosphorylation by protein kinase $\mathrm{M} \zeta$ maintains late-phase long-term potentiation. J Neurosci 2005;25:1979-1984.

89 Kelly MT, Crary JF, Sacktor TC: Regulation of protein kinase $M \zeta$ synthesis by multiple kinases in long-term potentiation. J Neurosci 2007;27:3439-3444.
$\$ 90$ Ling DSF, Benardo LS, Sacktor TC: protein kinase $\mathrm{M} \zeta$ enhances excitatory synaptic transmission by increasing the number of active postsynaptic AMPA receptors. Hippocampus 2006;16:443-452.

-91 Bliss TVP, Collingridge GL, Larcoche S: ZAP and ZIP a story to forget. Science 2006; 313:1058-1059.

-92 Oster H, Eichele G, Leitges M: Differential expression of atypical PKCs in the adult mouse brain. Brain Res Mol Brain Res 2004; 127:79-88.

93 Crary JF, Shao CY, Mirra SS, Hernandez AI, Sacktor TC: Atypical protein kinase $\mathrm{C}$ in neurodegenerative disease: $\mathrm{PKM} \zeta$ aggregates with limbic neurofibrillary tangles and AMPA receptors in Alzheimer diseases. J Neuropathol Exp Neurol 2006;65:319326.

94 Puls A, Schmidt S, Grawe F, Stabel S: Interaction of protein kinase $\mathrm{C} \zeta$ with ZIP a novel protein kinase C-binding protein. Proc Natl Acad Sci USA 1997;94:6191-6196.

$\$ 95$ Gong J, Bezanilla M, van Huizen R, Derin R, Li M: Differential stimulation of PKC phosphorylation of potassium channels by ZIP1 and ZIP2. Science 1999;285:15651569.

96 Hochstrasser M: Ubiquitin-dependent protein degradation. Annu Rev Genet 1996;30: 405-439.

$\$ 97$ Schnell JD, Hicke L: Non-traditional functions of ubiquitin and ubiquitin-binding proteins. J Biol Chem 2003;278:3585735860.

$\$ 98$ DiAntonio A, Haghighi AP, Portman SL, Lee JD, Amaranto AM, Goodman CS: Ubiquitination-dependent mechanisms regulate synaptic growth and function. $\mathrm{Na}-$ ture 2001;412:449-452.

99 Burbea M, Dreier L, Dittman JS, Grunwald ME, Kaplan JM: Ubiquitin and AP180 regulate the abundance of GLR-1 glutamate receptors at postsynaptic elements in C. elegans. Neuron 2002;35:107-120.

100 Hegde AN, DiAntonio A: Ubiquitin and the synapse. Nat Rev Neurosci 2002;3:854861.

101 Murphey RK, Godenschwege TA: New roles for ubiquitin in the assembly and function of neuronal circuits. Neuron 2002; 36:5-8.

102 Speese DD, Trotta N, Rodesch CK, Aravamudan $B$, Broadie $K$ : The ubiquitin proteasome system acutely regulates presynaptic protein turnover and synaptic efficacy. Curr Biol 2003;13:899-910.

103 DiAntonio A, Hicke L: Ubiquitin-dependent regulation of the synapse. Annu Rev Neurosci 2004;27:223-246.

104 Kato A, Rouach N, Nicoll RA, Bredt DS: Activity-dependent NMDA receptor degradation mediated by retrotranslocation and ubiquitination. Proc Natl Acad Sci USA 2005;102:5600-5605.
105 Ehlers MD: Activity level controls postsynaptic composition and signaling via the ubiquitin-proteasome system. Nat Neurosci 2003;6:231-242.

106 Yi JJ, Ehlers MD: Ubiquitin an protein turnover in synapse function. Neuron 2005;47:629-632.

107 Carroll RC, Beattie EC, Xia H, Luscher C, Altschuler Y, Nicoll RA, Malenka RC, von Zastrow M: Dynamin-dependent endocytosis of ionotropic glutamate receptors. Proc Natl Acad Sci USA 1999;96:1411214117.

108 Wang YT, Linden DJ: Expression of cerebellar long-term depression requires postsynaptic clathrin-mediated endocytosis. Neuron 2000;25:649-662.

109 Metzler M, Li B, Gan L, Georgiou J, Gutekunst CA, Wang Y, Torre E, Devon RS, Oh R, Legendre-Guillemin V, Rich M, Alvarez $C$, Gertsenstein M, McPherson PS, Nagy A, Wang YT, Roder JC, Raymond LA, Hayden MR: Disruption of the endocytic protein HIP1 results in neurological deficits and decreased AMPA receptor trafficking. EMBO J 2003;22:3254-3266.

110 Patrick GN, Bingol B, Weld HA, Schuman EM: Ubiquitin-mediated proteasome activity is required for agonist-induced endocytosis of GluRs. Curr Biol 2003;13:20732081.

111 Jiang YH, Armstrong D, Albrecht U, Atkins CM, Noebels JL, Eichele G, Sweatt JD, Beaudet AL: Mutation of the Angelman ubiquitin ligase in mice causes increased cytoplasmic p53 and deficits of contextual learning and long-term potentiation. Neuron 1998;21:799-811.

112 Schaefer H, Rongo C: KEL-8 is a substrate receptor for CUL3-dependent ubiquitin ligase that regulates synaptic glutamate receptor turnover. Mol Biol Cell 2006;17: $1250-1260$.

113 Cho KO, Hunt CA, Kennedy MB: The rat brain postsynaptic density fraction contains a homolog of the Drosophila discslarge tumor suppressor protein. Neuron 1992;9:929-942.

114 Colledge M, Snyder EM, Crozier RA, Soderling JA, Jin Y, Langeberg LK, Lu H, Bear MF, Scott JD: Ubiquitination regulates PSD-95 degradation and AMPA receptors surface expression. Neuron 2003;40:595607.

115 Bingol B, Schuman EM: A proteasome-sensitive connection between PSD-95 and GluR1 endocytosis. Neuropharmacology 2004;47:755-763.

116 Walsh DM, Klyubin I, Fadeeva JV, Cullen WK, Anwyl R, Wolfe MS, Rowan MJ, Selkoe DJ: Naturally secreted oligomers of amyloid $\beta$ protein potently inhibit hippocampal long-term potentiation in vivo. Nature 2002;416:535-539. 
-117 Hsieh H, Boehm J, Sato C, Iwatsubo T, Tomita T, Sisodia Sl, Malinow R: AMPAR removal underlines $A \beta$-induced synaptic depression and dendritic spine loss. Neuron 2006;52:831-843.

-118 Park M, Penick EC, Edwards JG, Kauer JA, Ehlers MD: Recycling endosomes supply AMPA receptors for LTP. Science 2004;305: 1972-1975.

-119 Park M, Salgado JM, Ostroff L, Helton TD, Robinson CG, Harris KM, Ehlers MD: Plasticity-induced growth of dendritic spines by exocytic trafficking from recycling en dosomes. Neuron 2006;52:817-830.

120 Kopec CD, Li B, Wei W, Boehm J, Malinow R: Glutamate receptor exocytosis and spine enlargement during chemically induced long-term potentiation. J Neurosci 2006; 26:2000-2009.

-121 Braithwaite SP, Meyer G, Henley JM: Interactions between AMPA receptors and intracellular proteins. Neuropharmacology 2000;39:919-930.

-122 Henley JM: Proteins interactions implicated in AMPA receptor trafficking: a clear destination and an improving route map. Neurosci Res 2003;45:243-254.

$\checkmark 123$ Leonard AS, Davare MA, Horne MC, Garner CC, Hell JW: SAP97 is associated with the $\alpha$-amino-3-hydroxy-5-methylisoxazole-4-propionic acid receptor GluR1 subunit. J Biol Chem 1998;273:19518-19524.

124 Cai C, Coleman SK, Niemi K, Keinanen K: Selective binding of synapse-associated protein 97 to GluR-A $\alpha$-amino-5-hydroxy3-methyl-4-isoxazole propionate receptor subunit is determined by a novel sequence motif. J Biol Chem 2002;277:31484-31490.

-125 Valtschanoff JG, Burette A Davare MA, Leonard AS, Hell JW, Weinberg RJ: SAP97 concentrates at the postsynaptic density in cerebral cortex. Eur J Neurosci 2000;12: 3605-3614.

-126 Colledge M, Dean RA, Scott GK, Langeberg LK, Huganir RL, Scott JD: Targeting of PKA to glutamate receptors through a MAGUK-AKAP complex in process citation. Neuron 2000;27:107-119.

-127 Tavalin SJ, Colledge M, Hell JW, Langeberg LK, Huganir RL, Scott JD: Regulation of GluR1 by the A-kinase anchoring protein 79 AKAP79 signaling complex shares properties with long-term depression. J Neurosci 2002;22:3044-3051.

-128 Gardoni F, Mauceri D, Fiorentini C, Bellone C, Missale C, Cattabeni F, Di Luca M: CaMKII-dependent phosphorylation regulates SAP97/NR2A interaction. J Biol Chem 2003;278:44745-44752.

-129 Mauceri D, Cattabeni F, Di Luca M, Gardoni F: Calcium/calmodulin-dependent protein kinase II phosphorylation drives synapse-associated protein 97 into spines. J Biol Chem 2004;279:23813-23821.
130 Kim CH, Takamiya K, Petralia RS, Sattler R, Yu S, Zhou W, Kalb R, Wenthold R, Huganir R: Persistent hippocampal CA1 LTP in mice lacking the C-terminal PDZ ligand of GluR1. Nat Neurosci 2005;8:985987.

131 Walensky LD, Blackshaw S, Liao D, Watkins CC, Weier HU, Parra M, Huganir RL, Conboy JG, Mohandas N, Snyder SH: A novel neuron-enriched homolog of the erythrocyte membrane cytoskeletal protein 4.1. J Neurosci 1999;19:6457-6467.

132 Fischer M, Kaech S, Knutti D, Matus A: Rapid actin-based plasticity in dendritic spines. Neuron 1998;20:847-854.

133 Coleman SK, Cai C, Mottershead DG, Haapalahti JP, Keinanen K: Surface expression of GluR-D AMPA receptor is dependent on an interaction between its C-terminal domain and a 4.1 protein. J Neurosci 2003;23: 798-806.

134 Dong H, O’Brien RJ, Fung ET, Lanahan AA, Worley PF, Huganir RL: GRIP: a synaptic PDZ domain-containing protein that interacts with AMPA receptors. Nature 1997; 386:279-284

135 Srivastava S, Osten P, Vilim FS, Khatri L, Inman G, States B, Daly C, DeSouza S, Abagyan R, ValtschanoffJG, Weinberg RJ, Ziff EB: Novel anchorage of GluR2/3 to the postsynaptic density by the AMPA receptor-binding protein ABP. Neuron 1998;21: 581-591.

136 Dong H, Zhang P, Song I, Petralia RS, Liao D, Huganir RL: Characterization of the glutamate receptor-interacting proteins GRIP1 and GRIP2. J Neurosci 1999;19: 6930-6941.

137 Ye B, Liao D, Zhang X, Zhang P, Dong H, Huganir RL: GRASP-1: a neuronal RasGEF associated with the AMPA receptor/GRIP complex. Neuron 2000;26:603-617.

138 Ye B, Sugo N, Hurn PD, Huganir RL: Physiological and pathological caspase cleavage of the neuronal RasGEF GRASP-1 as detected using a cleavage site-specific antibody. Neuroscience 2002;114:217-227.

139 Torres R, Firestein BL, Dong H, Staudinger J, Olson EN, Huganir RL, Bredt DS, Gale NW, Yancopoulos GD: PDZ proteins bind cluster and synaptically colocalize with Eph receptors and their ephrin ligands. Neuron 1998;21:1453-1463.

140 Gale NW, Yancopoulos GD: Ephrins and their receptors: a repulsive topic? Cell Tissue Res 1997;290:227-241.

141 Brückner K, Pablo Labrador J, Scheiffele P, Herb A, Seeburg PH, Klein R: EphrinB ligands recruit GRIP family PDZ adaptor proteins into raft membrane microdomains. Neuron 1999;22:511-524.

142 Seog DH: Glutamate receptor-interacting protein 1 protein binds to the microtubuleassociated protein. Biosci Biotechnol Biochem 2004;68:1808-1810.
143 Wyszynski M, Kim E, Dunah AW, Passafaro M, Valtschanoff JG, Serra-Pages C, Streuli M, Weinberg RJ, Sheng M: Interaction between GRIP and liprin- $\alpha /$ SYD2 is required for AMPA receptor targeting. Neuron 2002;34:39-52.

144 Shin H, Wyszynski M, Huh KH, Valtschanoff JG, Lee JR, Ko J, Streuli M, Weinberg RJ, Sheng M, Kim E: Association of the kinesin motor KIF1A with the multimodular protein liprin- $\alpha$. J Biol Chem 2003;278: 11393-11401.

145 Ko J, Kim S, Valtschanoff JG, Shin H, Lee J-R, Sheng M, Premont RT, Weinberg RJ, Kim E: Interaction between liprin- $\alpha$ and GIT1 is required for AMPA receptor targeting. J Neurosci 2003;23:1667-1677.

146 Xia J, Zhang X, Staudinger J, Huganir RL: Clustering of AMPA receptors by the synaptic PDZ domain-containing protein PICK1. Neuron 1999;22:179-187.

147 Dev KK, Nakanishi S, Henley JM: The PDZ domain of PICK1 differentially accepts protein kinase C- $\alpha$ and GluR2 as interacting ligands. J Biol Chem 2004;279:4139341397.

148 Perez JL, Khatri L, Chang C, Srivastava S, Osten P, Ziff EB: PICK1 targets activated protein kinase $\mathrm{C} \alpha$ to AMPA receptor clusters in spines of hippocampal neurons and reduces surface levels of the AMPA-type glutamate receptor subunit 2. J Neurosci 2001;21:5417-5428.

$149 \mathrm{Lu} \mathrm{W,} \mathrm{Ziff} \mathrm{EB:} \mathrm{PICK1} \mathrm{interacts} \mathrm{with} \mathrm{ABP/}$ GRIP to regulate AMPA receptor trafficking. Neuron 2005;47:407-421.

150 Meyer G, Varoqueaux F, Neeb A, Oschlies $\mathrm{M}$, Brose N: The complexity of PDZ domain-mediated interactions at glutamatergic synapses: a case study on neuroligin. Neuropharmacology 2004;47:724-733.

151 Steiner P, Alberi S, Kulangara K, Yersin A, Sarria JC, Regulier E, Kasas S, Dietler G, Muller D, Catsicas S, Hirling H: Interactions between NEEP21, GRIP1 and GluR2 regulate sorting and recycling of the glutamate receptor subunit GluR2. EMBO J 2005;24:2873-2884.

152 Henley JM, Nishimune A, Nash SR, Nakanishi S: Use of the two-hybrid system to find novel proteins that interact with AMPA receptor subunits. Biochem Soc Trans 1997;25:838-841.

153 Nishimune A, Isaac JTR, Molnar E, Noel J, Nash SR, Tagaya M, Collingridge GL, Nakanishi S, Henley JM: NSF binding to GluR2 regulates synaptic transmission. Neuron 1998;21:87-97.

154 Schiavo G, Gmachl MJS, Stenbeck G, Sollner TH, Rothman JE: A possible docking and fusion particle for synaptic transmissions. Nature 1995;378:733-736. 
155 Lee SH, Liu L, Wang YT, Sheng M: Clathrin adaptor AP2 and NSF interact with overlapping sites of GluR2 and play distinct roles in AMPA receptor trafficking and hippocampal LTD. Neuron 2002;36:661674.

-156 Noel J, Ralph GS, Pickard L, Williams J, Molnar E, Uney JB, Collingridge GL, Henley JM: Surface expression of AMPA receptors in hippocampal neurons is regulated by an NSF-dependent mechanism. Neuron 1999;23:365-376.

157 Kirchhausen T: Adaptors for clathrin-mediated traffic. Annu Rev Cell Dev Biol 1999; 15:705-732.

-158 Chen L, Chetkovich DM, Petralia RS, Sweeney NT, Kawasaki Y, Wenthold RJ, Bredt DS, Nicoll RA: Stargazin regulates synaptic targeting of AMPA receptors by two distinct mechanisms. Nature 2000;408:936943.

159 Hashimoto K, Isomura Y, Kato N: Occurrence of dentate granule cell LTP without proximal dendritic $\mathrm{Ca}^{2+}$ increase. Neuroreport 1999;10:2509-2513.

-160 Schnell E, Sizemore M, Karimzadegan S, Chen L, Bredt DS, Nicoll RA: Direct interactions between PSD-95 and stargazin control synaptic AMPA receptor number. Proc Natl Acad Sci USA 2002;99:13902-13907.

-161 Tomita S, Chen L, Kawasaki Y, Petralia RS, Wenthold RJ, Nicoll RA, Bredt DS: Functional studies and distribution define a family of transmembrane AMPA receptor regulatory proteins. J Cell Biol 2003;161: 805-816.

-162 Tomita S, Fukata M, Nicoll RA, Bredt DS: Dynamic interaction of stargazin-like TARPs with cycling AMPA receptors at synapses. Science 2004;303:1508-1511.

-163 Tomita S, Adesnik H, Sekiguchi M, Zhang W, Wada K, Howe JR, Nicoll RA, Bredt DS: Stargazin modulates AMPA receptor gating and trafficking by distinct domains. Nature 2005;435:1052-1058.

164 Tomita S, Stein V, Stocker TJ, Nicoll RA, Bredt DS: Bidirectional synaptic plasticity regulated by phosphorylation of stargazinlike TARPs. Neuron 2005;45:269-277.

$\checkmark 165$ Nicoll RA, Tomita S, Bredt DS: Auxiliary subunits assist AMPA-type glutamate receptors. Science 2006;311:1253-1256.
166 Tomita S, Shenoy A, Fukata Y, Nicoll RA, Bredt DS: Stargazin interacts functionally with the AMPA receptor glutamate-binding module. Neuropharmacology 2006;52: 87-91.

167 Osten P, Srivastava S, Inman GJ, Vilim FS Khatri L, Lee LM, States BA, Einheber S, Milner TA, Hanson PI, Ziff EB: The AMPA receptor GluR2 C-terminus can mediate a reversible ATP-dependent interaction with NSF and $\alpha$ - and $\beta$-SNAPs. Neuron 1998;21: 99-110.

168 Clary DO, Griff IC, Rothman JE: SNAPs a family of NSF attachment proteins involved in intracellular membrane fusion in animals and yeast. Cell 1990;61:709-721.

169 DeBello WM, O'Connor V, Dresbach T, Whiteheart SW, Wang SS, Schweizer FE, Betz H, Rothman JE, Augustine GJ: SNAPmediated protein-protein interactions essential for neurotransmitter release. Nature 1995;373:626-630

170 Lledo PM, Zhang X, Sudhof TC, Malenka RC, Nicoll RA: Postsynaptic membrane fusion and long-term potentiation. Science 1998;279:399-403.

171 Hanley JG, Khatri L, Hanson PI, Ziff EB: NSF ATPase and $\alpha-/ \beta$-SNAPs disassemble the AMPA receptor-PICK1 complex. Neuron 2002;34:53-67.

172 Hayashi T, Umemori H, Mishina M, Yamamoto T: The AMPA receptor interacts with and signals through the protein tyrosine kinase Lyn. Nature 1999;397:72-76.

173 Poo MM: Neurotrophins as synaptic modulators. Nat Rev Neurosci 2001;2:24-32.

174 Yamada K, Mizuno M, Nabeshima T: Role for brain-derived neurotrophic factor in learning and memory. Life Sci 2002;70: 735-744.

175 Zakharenko SS, Patterson SL, Dragatsis I, Zeitlin SO, Siegelbaum SA, Kandel ER, Morozov A: Presynaptic BDNF required for a presynaptic but not postsynaptic component of LTP at hippocampal CA1-CA3 synapses. Neuron 2003;39:975-990.

176 Caldeira MV, Melo CV, Pereira DB, Carvalho R, Correia SS, Backos DS, Carvalho AL, Esteban JA, Duarte CB: BDNF regulates the expression and the synaptic delivery of AMPA receptor subunits in hippocampal neurons. J Biol Chem 2007;282: 12619-12628.
177 Rongo C, Whitfield CW, Rodal A, Kim SK, Kaplan JM: LIN-10 is a shared component of the polarized protein localisation pathways in neurons and epithelia. Cell 1998;94: 751-759.

178 Stricker NL, Huganir RL: The PDZ domains of mLin-10 regulate its trans-Golgi network targeting and the surface expression of AMPA receptors. Neuropharmacology 2003;45:837-848.

179 Tomita S, Fujita T, Kirino Y, Suzuki T: PDZ domain-dependent suppression of NF- $\mathrm{B}$ / p65-induced $A \beta 42$ production by a neuron-specific X11-like protein. J Biol Chem 2000;275:13056-13060.

180 Wang Y, Small DL, Stanimirovic DB, Morley P, Durkin JP: AMPA receptor-mediated regulation of a Gi-protein in cortical neurons. Nature 1997;389:502-504.

181 Sanz L, Sanchez P, Lallena M-J, Diaz-Meco MT, Moscat J: The interaction of p62 with RIP links the atypical PKCs to NF- $\mathrm{B}$ activation. EMBO J 1999; 18:3044-3053.

182 Cariou B, Perdereau D, Cailliau K, Browaeys-Poly E, Bereziat V, Vasseur-Cognet M, Girard J, Burnol AF: The adapter protein ZIP binds Grb14 and regulates its inhibitory action on insulin signaling by recruiting protein kinase $\mathrm{C} \zeta$. Mol Cell Biol 2002;22:6959-6970.

183 Croci C, Brandstatter JH, Enz R: ZIP3 a new splice variant of the $\mathrm{PKC}-\zeta$-interacting protein family binds to $\mathrm{GABA}_{\mathrm{C}}$ receptors $\mathrm{PKC}$ $\zeta$ and Kvß2. J Biol Chem 2003;278:61286135.

184 Moscat J, Diaz-Meco M, Wooten MW: Signal integration and diversification through the p62 scaffold protein. Trends Biochem Sci 2006;32:95-100

185 Geetha T, Jiang J, Wooten MW: Lysine 63 polyubiquitination of the nerve growth factor receptor TrkA directs internalization and signaling. Mol Cell 2005;20:301-312.

186 Seibenhener ML, Babu JR, Geetha T, Wong HC, Krishna NR, Wooten MW: Sequestsome $1 /$ p62 is a polyubiquitin chain binding protein involved in ubiquitin proteasome degradation. Mol Cell Biol 2004;24: 8055-8068.

187 Thoenen H: Neurotrophins and neuronal plasticity. Science 1995;270:593-596. 